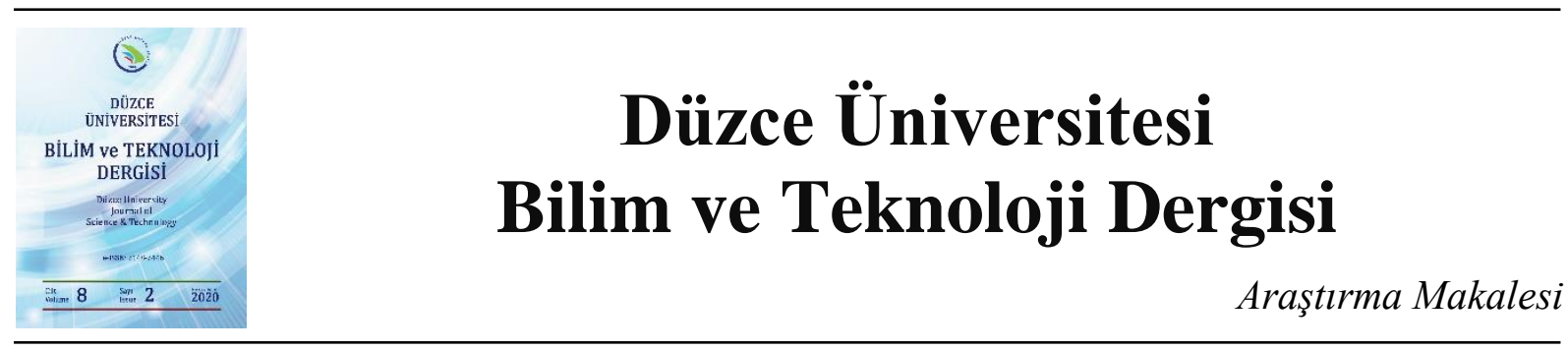

\section{Kültürel Odaklı Peyzaj Biyografisinin Oluşturulması: Üsküdar Kıyı Bandı Örneği}

\author{
(iD) Selma GÜNER ${ }^{\mathrm{a}}$, (DD Pınar GÜLTEKIN ${ }^{\mathrm{a} *}$ \\ ${ }^{a}$ Peyzaj Mimarliğı Bölümü, Orman Fakültesi, Düzce Üniversitesi, Düzce, TÜRKIYYE \\ * Sorumlu yazartn e-posta adresi: pinargultekin@duzce.edu.tr
}

DOI : 10.29130/dubited.579841

\begin{abstract}
ÖZET
Bu çalışmada, İstanbul ili Üsküdar ilçesi içerisinde kıyı bandında yer alan tüm kültür varlıklarının envanteri oluşturulmuştur. Her bir kültür varlığının geçmişten günümüze çevreleri ile birlikte varoluş süreçleri değerlendirilmiş, kültürel varlıklara ilişkin kent halkının farkındalıkları saptanmış, kültürel varlıkların geçmiş fotoğraflarına ulaşılarak geçmişten günümüze kıyaslama olanağı sağlanmıştır. Kentsel kültürel varlıkların sürdürülebilirliklerinin sağlanması ve ulusal kimliğe katkı sağlanmasına ilişkin stratejiler üretilmiş, kültürel varlıklar dış mekân çevrelerindeki değişimleri ile peyzaj mimarlığı bakış açısı ile yorumlanmıştır. Çalışma alanında yaşayan kent halkına, kentsel kültürel miras farkındalıklarını ölçmek amacı ile anket uygulanmış ayrıca, her bir kentsel-kültürel miras öğesi için çalışma kapsamında geliştirilen gözlem formu ile değerlendirme yapılmıştır. Yerel yönetim, kamu kurumları, dernekler, üniversitelerde görev yapan uzmanlar ile sözlü görüşmeler yapılarak katılımcı bir çerçevede değerlendirmeler yapılmıştır. Sonuç olarak çalışma alanındaki kentsel kültürel miraslar için, ilgili yasa ve yönetmelikler çerçevesinde, paydaş görüşleri doğrultusunda peyzaj biyografilerinden yararlanılarak koruma-kullanma, yeniden işlevlendirme stratejileri geliştirilmiştir.
\end{abstract}

Anahtar Kelimeler: Kültürel miras, peyzaj biyografisi, Kültürel peyzaj, Kentsel miras, Üsküdar

\section{Cultural Oriented Landscape Biography: Example of Üsküdar Coastal Zone}

\begin{abstract}
In this study, inventory of all cultural assets in the coastal band in the Üsküdar district of İstanbul is produced. The existence processes of each cultural entity from past to present have been evaluated, awareness of cultural assets have been determined and urban cultural past photographs of the urban people have been reached and compared. The position and sustainability of cultural assets in existing projects prepared for the field are discussed within the framework of landscape architecture discipline. Strategies for ensuring sustainability and contributing to national identity have been developed. In order to measure the awareness of urban cultural heritage, a questionnaire was applied to the urban people living in the study area and evaluation was made with the observation form developed within the scope of the study for each urban-cultural heritage item. Oral interviews were conducted with experts working in local government, public institutions, associations and universities and evaluations were made within a participatory framework. As a result, conservation-use and re-use strategies have been developed for urban cultural heritage for the study area by utilizing landscape biographies in line with stakeholder views within the framework of relevant laws and regulations.
\end{abstract}

Keywords: Urban, Cultural Heritage, Landscape Biography, İstanbul 


\section{GİRIS}

İnsanoğlu var olduğundan beri ortaya konan eserler, nesiller arası bağlantıyı ve devamı sağlamış, gelecek kullanımlara yön vermişlerdir. Mimari eserler ve anıtlar da çevreleriyle beraber ele alındığında "çevre düzeni" ve" mekân " yaratılmasına katkı sağlamaktadır [1]. Bir kentin tarihî mekânları olarak kendini gösteren kültürel miras, toplum refahının en değerli ve gelecek nesillere aktarılması gereken parçasıdır. Kültürel mirasın korunmasının ilke edinilmesi, kentli için sağlıklı bir yaşam olanağı sağlamasının yanı sıra o kentin kültürel kimliğinin tanınmasına da katkı sağlamış olur [2]. Günümüz modern kentleri ve metropolleri içerisinde, kültürel miras alanları ve etki alanlarının saptanması ve korunması, öncelikle kent kimliğine, daha üst ölçekte ise ulusal kimliğe katkı sağlamaktadır.

Tarihi çevre bir bütündür ve bu bütünün parçaları; binalar, mekan organizasyonları, sokaklar, kaldırımlar, kullanılan malzemeler, anıt ağaçlar, yeşil alanlar şeklinde belirtilmekte, kültürel peyzaj unsurlarını kapsayan çevrenin tümü olarak değerlendirilmektedir [3]. Bir başka deyişle tarihi çevre, yaşadığımız alanlarda tarih öncesinden günümüze kadar geçen süreçte varlık göstermiş medeniyetlerin birikimi ve ürünüdür [4]. Geçmiş uygarlıklardan geriye kalan yerleşimler ve kalıntılar tarihi çevremizi oluşturmaktadır. 19. yy'da tarihî çevre ve koruma, anıt niteliğindeki yapıları korumaya yönelik olup, zaman içerisinde koruma kavramında "anıt" ölçeğinden "çevre" ölçeğine doğru bir gelişim izlenmektedir [5].

Kültürel miras, tek bir mimari yapı ya da tarihi kalıntılar değil; bunun yanı sıra örf, gelenek, görenek ve sözlü kültür unsurları kapsamaktadır [6]. Yazgan ve Erdoğan'a göre; tarihi kentler ve özgün yapılar sahip olunan en önemli kültürel miraslarımızdandır. Tarihi çevreler ve kültürel miras alanları, insan ölçeğine göre düzenlenmiş, sosyal ilişkileri olumlu yönde etkileyen, öğretici, ilgi çekici olup, çevresinin açık ve yeşil alanıyla, doğal ve kültürel peyzaj özellikleriyle bütünleştiği ölçüde değer kazanan mekânlardır [7].

Kültürel mirasın korunmasına yönelik Türkiye'nin de taraf olduğu uluslararası düzeyde sözleşmeler bulunmaktadır. Avrupa Peyzaj Sözleşmesi peyzajın korunmasını, yönetimini ve planlamasını geliştirmek ve peyzaj konularında Avrupa işbirliğini düzenlemek amacıyla imzalanmıştır. Avrupa Peyzaj Sözleşmesi çok geniş bir tanımlama ile sadece kentsel ölçekte değil, hem kırsal hem de kentsel ölçekte sürdürülebilir gelişmenin peyzajı korumak, yönetmek ve planlamaya dayandığını belirtmektedir $[5,8,9]$.

Kültürel peyzajların geçmişten günümüze geçirdiği süreçleri ortaya koyan bir terim olarak "peyzaj biyografisi" kavramı karşımıza çıkmaktadır. Biyografi kavramı Türk Dil Kurumu [10] tarafından belirtildiği üzere "özgeçmiş" olarak ifade edilmektedir. Peyzaj biyografisi ise peyzajların doğal ve insani unsurlardan nasıl etkilendiklerini, varoluşlarından günümüze değin geçen süreci özetlediği söylenebilmektedir. Kolen [11] tarafından belirtildiği üzere peyzaj biyografisi kavramı ilk olarak arkeologlar tarafından 1990'lı yıllarda Hollanda literatürüne girmiştir [12]. Peyzaj Biyografisi, belirli bir bölgenin tarih öncesi dönemlerinden bugüne kadar geçen süre içerisinde uzun dönem değişimlerinin, mekânsal dönüşümler, değerler, sosyal ve ekonomik gelişmelerin birbiriyle olan ilişkileri arasındaki karmaşık etkileşimin üzerinde yoğunlaşarak analiz edilebilir bir şekilde değerlendirilmesidir [13].

Doğal/kültürel/ekolojik süreçler peyzajları değiştirmekte ve dönüştürmektedir. Bu değişimlerin "biyografik" açıdan tanımlanması, peyzajın ve onu oluşturan her bir ünitenin zamana dayalı katmanlar sayesinde daha kapsamlı bir şekilde anlaşılmasını sağlamaktadır. Sosyal bakış açısıyla değerlendirildiğinde peyzaj biyografisi, tarihsel peyzaj araştırması ile peyzaj planlama, peyzaj tasarımı, şehir planlaması ve halkın katılımını bütünleştirmeyi amaçlamaktadır [14].

Peyzaj biyografisi son yıllarda literatürde yerini alan, peyzaj araştırmalarında kullanılan yeni bir alandır. Peyzaj biyografisinin oluşturulması ile ulusal kimliğin korunmasına katkı sağlanması, tarihi ve kültürel varlıkların (cami, kışla, saray, çeşme, sivil mimari örnekleri vb. yapılar) geçmişten günümüze nasıl korunduğunun ortaya konulması, afetler, yangınlar, savaşlar, vb. tarihte yaşanan önemli gelişmelerin, 
yasal düzenlemelerin, değişen toplumsal yapının, yaşanan teknolojik gelişmelerin kültür varlıkları ve fiziksel ortamı nasıl şekillendirdiğinin açıklanmasını sağlar.

Bu çalışmanın amacı; İstanbul'un tarihi, arkeolojik, coğrafi ve kültürel açılardan önem taşıyan ve aktarım merkezi konumunda bulunan Üsküdar İlçesi kıy bandı için peyzaj biyografisinin oluşturulmasıdır. Kültürel miras alanlarının yoğun bir şekilde bulunduğu İstanbul şehri dünyanın stratejik ve jeopolitik açıdan en önemli şehirlerinden biridir. Asya ve Avrupa kıtalarının birleşme noktasında yer alan İstanbul dünyanın içinden deniz geçen tek şehri olarak, yüzyıllar boyunca birçok uygarlığa ev sahipliği yapmıştır. İstanbul Marmara Denizi, Boğaziçi ve Haliç’in sardığı bir yarımada üzerinde bulunmaktadır. İstanbul, tarihi boyunca üç büyük imparatorluğa başkentlik yapmıştır. Roma, Bizans ve Osmanlı dönemlerinde yaklaşık olarak 1600 yıl başkent kalarak dünyada benzeri bulunmayan bir özelliğe sahip olmuştur [15].

Çalışma alanının bu sınır olarak tercih edilmesinin nedeni; İstanbul İli Üsküdar İlçesi'nde Üsküdar Meydanı ve Selimiye Kışlaları arasında kalan kıyı hattı ve $1 \mathrm{~km}$ gerisinin, Bizans ve Osmanlı döneminden kalan kültürel miras alanlarının yoğunlaştığı bir bölge olmasıdır.

Çalışma kapsamında İstanbul ili Üsküdar İlçesi içerisinde kıyı bandında yer alan tüm kültür varlıklarına ilişkin envanter oluşturulmuş, her bir kültür varlığının geçmişten günümüze çevreleri ile birlikte varoluş süreçleri ele alınmış, yöre halkının kentsel kültürel miras alanlarının farkındalıkları değerlendirilmiş, her bir alanın güncel fotoğrafları ve geçmiş fotoğrafları ile değerlendirilmesine olanak sağlayan arşiv oluşturulmuş, uzman gözlem formları ile kültürel mirasın daha objektif değerlendirilmesine olanak sağlanmış, çalışma alanı için söz konusu projeler ve mevzuat çerçevesinde kültürel miras değerlerinin konumları ve varlıklarını devam ettirebilme düzeyleri peyzaj mimarlığı meslek disiplini içerisinde yorumlanmıştır.

\section{MATERYAL VE YÖNTEM}

\section{A. MATERYAL}

Çalışma alanı sınırı olarak Üsküdar kıyı bandı belirlenmiştir. Fethipaşa korusu ile Selimiye Kışlası arasında kalan hatta, kıyı çizgisinin yaklaşık $1 \mathrm{~km}$ gerisine kadar olan alan seçilmiştir. Bu hat içerisinde önemli bir yeşil doku olarak Doğancılar Park'1 yer almaktadır. Üsküdar Meydanı, Kızkulesi, Sultan III. Ahmet Çeşmesi, Mihrimah Sultan Camii, Gülfem Hatun Camii, Aziz Mahmud Hüdai Hz. Tekkesi, Ayazma Camii, Ayazma Çeşmesi, Eski Vapur İskelesi, Harem Otogarı, III. Selim Av Köşkü vb. pek çok önemli yapı çalışma sınırları içerisinde bulunmaktadır (Şekil 1).

Şekil 1'de belirtilen çalışma alanı içerisinde yer alan kültürel miraslara ilişkin veriler; literatür taraması, internet ve sosyal medyada ulaşılan geçmiş fotoğraflar, el çizimleri, tasvirler, haritalar, Üsküdar Belediyesi ve İstanbul Büyükşehir Belediyelerinden temin edilen 1/5000 ve 1/1000 ölçekli nazım ve uygulama imar planları ve raporları, yapılan sözlü görüşmeler, alana yönelik projeler sonucunda elde edilmiştir. 


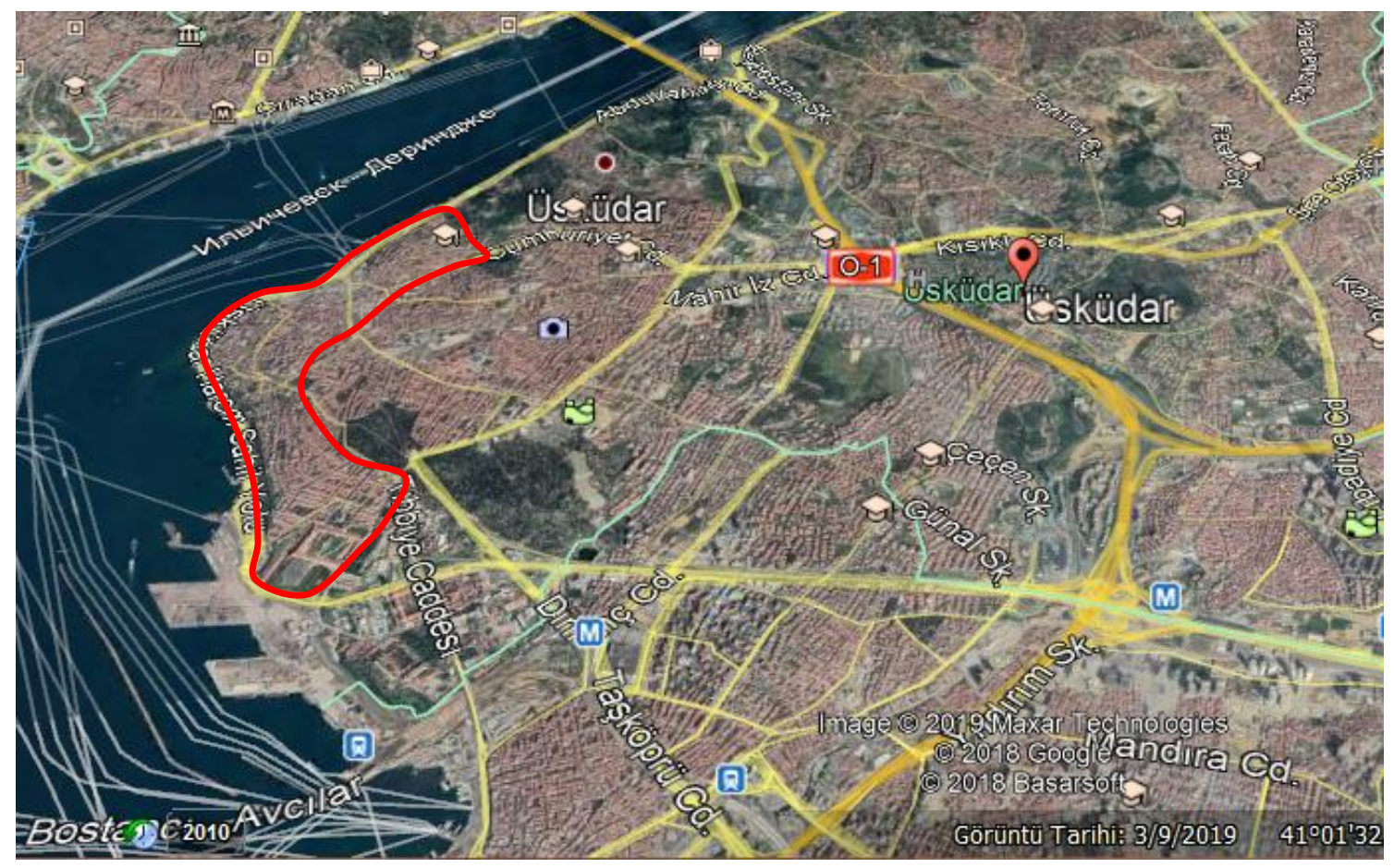

Şekil 1. Çalıșma alanı konumu ve sınırı [16]

\section{B. YÖNTEM}

Çalışmanın yöntemi; Envanter, analiz ve sentez olmak üzere 3 temel aşamadan oluşmaktadır.

1. Aşama: Literatür taraması (tez, makale, bildiri, ders notu, kitap vb. yazılı kaynaklar) ve arazi gözlemlerinden yararlanılmış, İstanbul Büyükşehir Belediyesi, Üsküdar Kaymakamlığı, İl Kültür ve Turizm Müdürlügü, Üsküdar Belediyesi, Çekül Vakfı, Tarih ve Kültür Vakıfları, Üniversiteden uzmanlar ile görüşmeler yapılarak alana ilişkin envanter çalışması yapılmıştır. 1870-2018 yılları arasında, kentsel- kültürel miraslara ilişkin fotoğraflar, tasvirler, el çizimlerine sosyal medya, internet, kütüphaneler, kamu ve yerel yönetimler, alanda yaşayan halkın kişisel arşivlerinden yararlanılarak ulaşılmıştır.

2. Aşama: Yöntemin analiz aşaması 3 bölümden oluşmaktadır.

a) Bölümde tüm kültürel miras alanlarının peyzaj mimarı bakış açısı ile objektif olarak değerlendirilebilmesi ve geçmişleri ile kıyaslanabilmesi amacı ile arazi çalışması yapılmış, kültürel miras elemanları fotoğraflanmıştır. Tüfekçioğlu [17] tarafından, tarihi çevrede görsel peyzaj kalite değerlendirmesi amacı ile geliştirilen gözlem değerlendirme formu, çalışma alanı ve konusuna adapte edilerek, her bir kültürel miras elemanı için uzman peyzaj mimarı tarafından, gözlem formları doldurulmuştur. Gözlem formu içerisinde; tutarlılık, okunabilirlik, komplekslilik, geçicilik, tasvir edilebilirlik, sahip çıkma, tarihsellik, doğallık, görsel ölçek ve mekân duygusu kavramları için, her bir kavram altında yer alan göstergeler var/yok şeklinde değerlendirilmiş ve kavramlar için belirlenen katsayılar ile çarpılmıştır. Her bir kültürel miras elemanına ilişkin 25-93 Aralığında puanlar elde edilmiş, düşük ve yüksek puan alan yapılar koşullarına bağlı olarak değerlendirilmiştir.

b) Peyzaj biyografisi yaklaşımının yöntemsel olarak ifade edilebilmesi için öncelikle araştırma alanı ve çevresindeki mekân-zamansal değişimi/dönüşümü, zaman içinde bu yapıların değişimini etkileyen yangınlar, savaşlar, depremler, değişen toplumsal yapı, sosyal ve 
teknolojik gelişmeler, mevzuat vb. faktörlerin kültürel miras yapılarına ve çevrelerine bıraktığı etki irdelenmiştir. Geçmiş fotoğraflar ve günümüz fotoğraflarına ilişkin arşiv oluşturulmuş, değişme veya değişmeme nedenleri yorumlanmış her bir kültürel miras elemanının ve toplam çalışma alanının peyzaj biyografileri elde edilmiştir.

c) Katılımcı bakış açısı ile çalışma alanı kentsel kültürel miras elemanlarına ilişkin kent halkı farkındalığının değerlendirilmesi amacı ile anket geliştirilmiş ve uygulanmıştır. Anketin uygulanacağ düzeyinde nüfusun 10 milyonun üzerinde olduğu evren için 384 olarak belirlenmiş, hatalı ve eksik anket olma ihtimaline karşın 400 kişiye uygulanmıştır. Anket kapsamında ankete katılanların sosyo demografik özellikleri ve farkındalıklarına ilişkin 2 temel bölüm kurgulanmıştır. Elde edilen veriler IBM Statistics SPSS 22.0 programında çözümlenmiş, sıklık ve yüzde analizleri ile ortalama analizleri uygulanarak açıklanmıştır.

Alana yönelik diğer paydaşların belirlenmesinde paydaş analizi ve katılımcılık konulu çalışmalar irdelenmiş̧tir [19] [20] [21] [22] [23]. Kamu ve yerel yönetimler, üniversitelerde görev yapan konunun uzmanları akademisyenler ve sivil toplum örgütleri temsilcileri ile sözlü görüşmeler yapılmıştır.

3. Aşama: Yöntemin sentez aşamasında çalışma alanı olan İstanbul Üsküdar İlçesi Kıyı bandı için kültürel odaklı peyzaj biyografisi oluşturulmuş, çalışma alanı bütüncül ve her bir kültürel miras elemanı bağlamında parçacıl olarak değerlendirilmiştir. Uzman görüşü, sivil toplum örgütleri ve karar vericiler ile yapılan görüşmeler, alanda yaşayan vatandaşların kentsel kültürel mirasa ilişkin, farkındalığ 1 bir arada yorumlanmıştır. Kentsel kültürel miras ile ilgili yasa ve yönetmelikler ile uygulanmakta olan ve uygulanması planlanan projeler çerçevesinde, paydaş görüşleri doğrultusunda peyzaj biyografilerinden yararlanılarak koruma-kullanma, yeniden işlevlendirme stratejileri geliştirilmiştir.

\section{BULGULAR VE TARTIȘMA}

\section{A. ÇALIŞMA ALANI KÜLTÜREL MİRAS ENVANTERİ}

İstanbul İli Üsküdar İlçesi’nde Üsküdar Meydanı ve Selimiye kışlaları arasında kalan kıyı hattı ve 1 km gerisi içerisinde yer alan tüm kültürel miras alanları; İstanbul Büyükşehir Belediyesi ve Üsküdar Belediyesinden temin edilen 1/5000 ve 1/1000 ölçekli nazım ve uygulama planları temel alınarak oluşturulan envanter haritası üzerine ArcGIS 10.1 ve AutoCAD 2013 programları kullanılarak işlenmiştir (Şekil 2). Çalışma alanında yapılan arazi çalışmalarında GPS kullanılarak tüm kültürel miras elemanları UTM koordinatları belirlenerek konumların sayısallaştırılması sağlanmıştır.

Çalışma kapsamında envanter oluşturulurken literatür taraması, arazi çalışmaları, Üsküdar Belediyesi, Çekül Vakfi, Tarih vakfi, Tarihi Kentler Birliği, İl Kültür ve Turizm Müdürlüğü, Üsküdar Kaymakamlığı, İstanbul 6 numaralı Kültür Varlıklarını Koruma Bölge Kurulu, çalışma alanına ilişkin tezler, kitaplar ve makalelerden yola çıkılarak envanter listesi oluşturulmuştur. Şekil 2'de görüldüğü üzere çalışma alanında; 32 adet kültürel miras varlığı bulunmaktadır. 


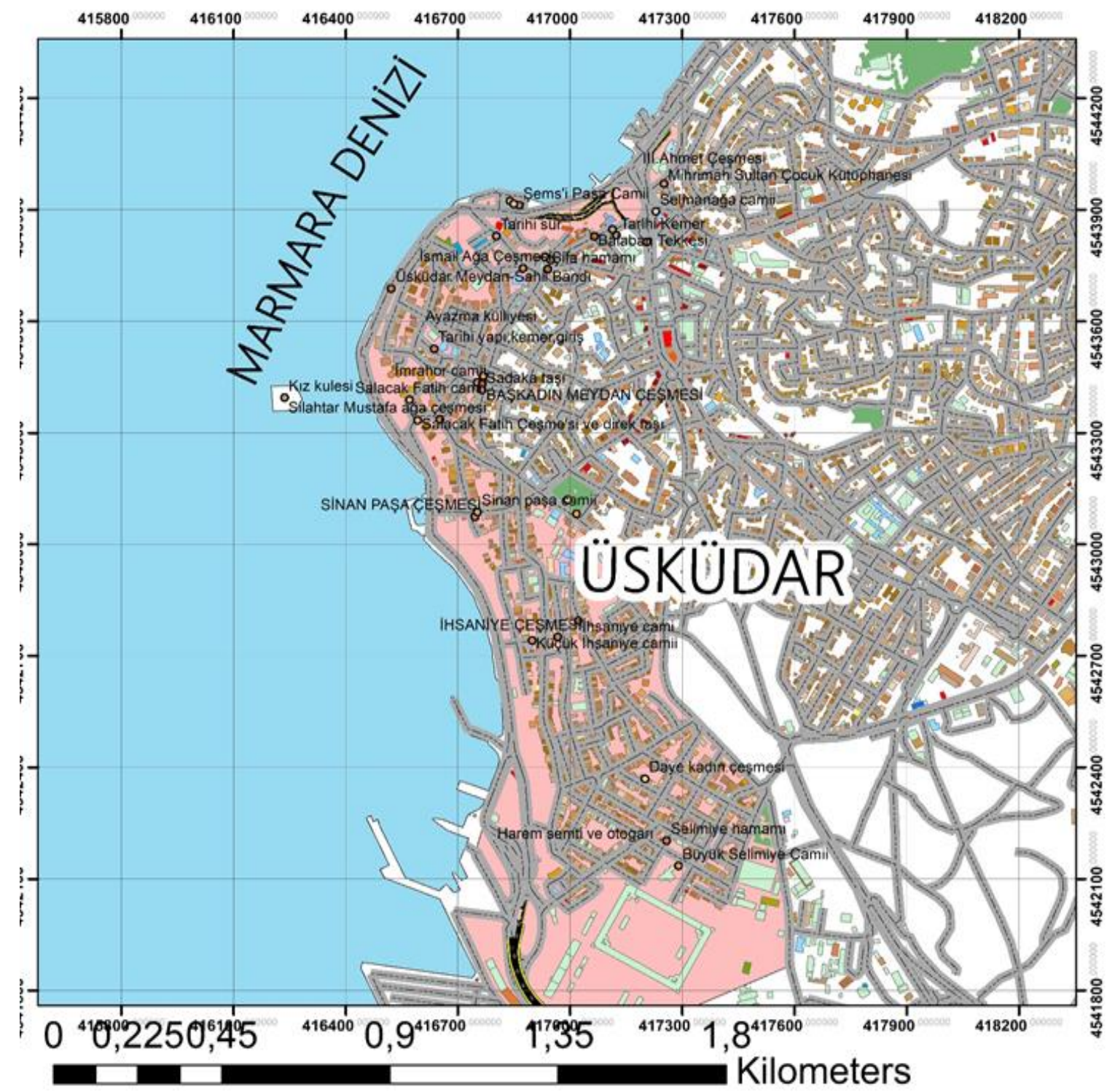

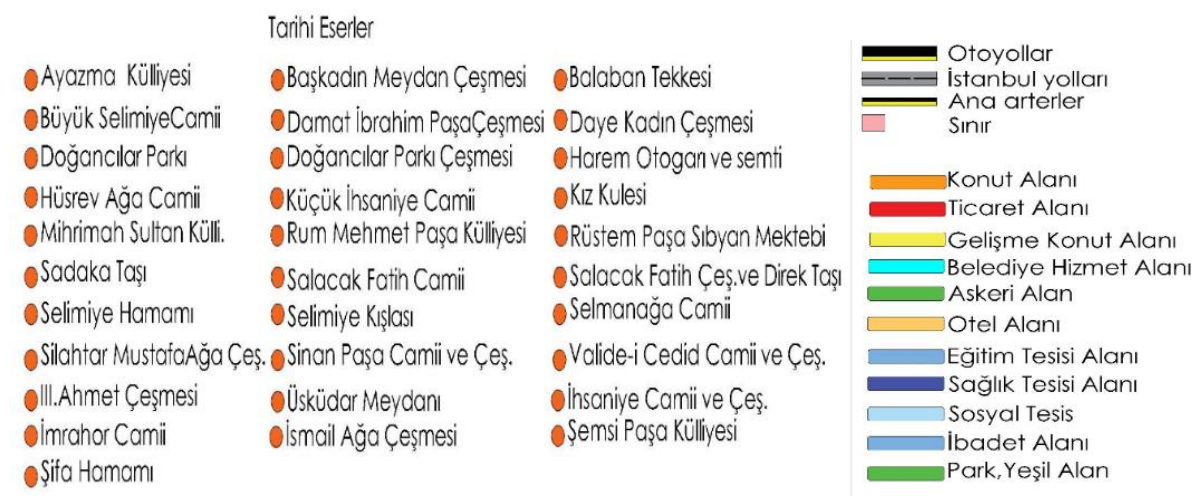

Şekil 2. Çalışma Alanı Tarihi ve Kültürel varlıklar Envanter Haritası

Çalışma alanı kültürel varlıklarına ilişkin liste Tablo 1'de türlerine göre belirtilmektedir. 
Tablo 1. Çalışma Alanı Tarihi ve Kültürel varlıklar listesi

\begin{tabular}{|c|c|c|c|c|}
\hline \multicolumn{5}{|c|}{ Kültürel Varlıklar Listesi } \\
\hline Külliyeler & Çeşmeler & Camiler & Parklar & Diğer \\
\hline Ayazma Külliyesi & Ayşe Sultan Çeşmesi & $\begin{array}{l}\text { Büyük Selimiye } \\
\text { Camii }\end{array}$ & $\begin{array}{l}\text { Doğancılar } \\
\text { Parkı }\end{array}$ & $\begin{array}{l}\text { Harem Otogarı ve } \\
\text { semti }\end{array}$ \\
\hline $\begin{array}{l}\text { Mihrimah Sultan } \\
\text { Külliyesi }\end{array}$ & $\begin{array}{l}\text { Başkadın Meydan } \\
\text { Çeşmesi }\end{array}$ & Hüsrev Ağa Camii & & Kız Kulesi \\
\hline $\begin{array}{l}\text { Rum Mehmet Paşa } \\
\text { Külliyesi }\end{array}$ & $\begin{array}{l}\text { Damat İbrahim Paşa } \\
\text { Çeşmesi }\end{array}$ & $\begin{array}{l}\text { Küçük İhsaniye } \\
\text { Camii }\end{array}$ & & $\begin{array}{l}\text { Rüstem Paşa } \\
\text { Sıbyan Mektebi }\end{array}$ \\
\hline \multirow[t]{8}{*}{ Şemsi Paşa Külliyesi } & Daye Kadın Çeşmesi & $\begin{array}{l}\text { Salacak Fatih } \\
\text { Camii }\end{array}$ & & Sadaka Taşı \\
\hline & Doğancılar Parkı Çeşmesi & Selmanağa Camii & & Selimiye Hamamı \\
\hline & $\begin{array}{l}\text { Salacak Fatih Çeşmesi ve } \\
\text { Direk Taşı }\end{array}$ & İmrahor Camii & & Selimiye Kışlası \\
\hline & $\begin{array}{l}\text { Silahtar Mustafa Ă̆a } \\
\text { Çeşmesi }\end{array}$ & & & $\begin{array}{l}\text { Üsküdar Meydanı } \\
\text { ve Sahil Bandı }\end{array}$ \\
\hline & $\begin{array}{l}\text { Sinan Paşa Camii ve } \\
\text { Çeşmesi }\end{array}$ & & & Şifa Hamamı \\
\hline & $\begin{array}{l}\text { Valide-i Cedid Camii ve } \\
\text { Cesmesi }\end{array}$ & & & Balaban Tekkesi \\
\hline & III.Ahmet Çeşmesi & & & \\
\hline & İhsaniye Camii ve Çeşmesi & & & \\
\hline
\end{tabular}

\section{İsmail Ağa Çeşmesi}

\section{B. KÜLTÜREL MİRAS ELEMANLARINA İLIŞKİN UZMAN DEĞERLENDİRMESİ}

Tüfekçioğlu [17] tarafından, tarihi çevrede görsel peyzaj kalite değerlendirmesi amacı ile geliştirilen uzman gözlem formu çalışma alanı ve konusuna adapte edilerek, her bir kültürel miras elemanı için uzman peyzaj mimarı tarafından, görsel değerlendirmeye dayalı gözlem formları doldurulmuştur. Gözlem formu içerisinde; tutarlılık, okunabilirlik, komplekslilik, geçicilik, tasvir edilebilirlik, sahip çıkma, tarihsellik, doğallık, görsel ölçek ve mekân duygusu kavramları için, her bir kavram altında yer alan göstergeler var/yok şeklinde değerlendirilmiş v kavramlar için belirlenen katsayılar ile çarpılmıştır. Tutarlılık, okunabilirlik, komplekslilik, geçicilik kavramları kat sayısı "1", Tasvir edilebilirlik, sahip çıkma, tarihsellik, mekân duygusu kavramları kat sayısı "2", doğallık ve görsel ölçek kat sayıları "3", mekan duygusu kat sayıs1 "4" olarak belirlenmiştir.

Görsel peyzaj kalitesini oluşturan kavramlar arasında bir hiyerarşi hakimdir. Bu hiyerarşiden ortaya çıkan sonuca göre kavramlar toplamda 100 puan oluşturacak şekilde dağılım yapılmış ve değerlendirilmiştir. Değerlendirilen kavramların toplam peyzaj kalitesi hesaplanırken eşit puan üzerinden bir değerlendirme yapılamayacağı öngörülmüştür. 
Tablo 2. Kültürel Miras Elemanlarına İlişkin Gözlem Formu Değerlendirmeleri

\begin{tabular}{|c|c|c|c|c|c|c|c|c|c|c|c|c|}
\hline No & $\begin{array}{l}\text { Mekan } \\
\text { adı }\end{array}$ & $\begin{array}{l}\text { Tuta } \\
\text { rlılık }\end{array}$ & $\begin{array}{c}\text { Okuna } \\
\text { bilirlik }\end{array}$ & $\begin{array}{l}\text { Kompl } \\
\text { ekslilik }\end{array}$ & $\begin{array}{l}\text { Geçi } \\
\text { cilik }\end{array}$ & $\begin{array}{l}\text { Tasvir } \\
\text { edilebil } \\
\text { irlik }\end{array}$ & $\begin{array}{l}\text { Sahip } \\
\text { çıma }\end{array}$ & $\begin{array}{l}\text { Tarihsell } \\
\text { ik }\end{array}$ & Doğallık & $\begin{array}{l}\text { Görsel } \\
\text { ölçek }\end{array}$ & $\begin{array}{l}\text { Mekan } \\
\text { duygusu }\end{array}$ & $\begin{array}{l}\text { Mekanın } \\
\text { toplam } \\
\text { puanı }\end{array}$ \\
\hline 1 & $\begin{array}{l}\text { Ayazma } \\
\text { Külliyesi }\end{array}$ & 5 & 5 & 4 & 2 & 8 & 8 & 10 & 9 & 15 & 20 & 85 \\
\hline 2 & $\begin{array}{l}\text { Başkadn } \\
\text { Meydan } \\
\text { Çeşmesi }\end{array}$ & 2 & 1 & 1 & 1 & 2 & 6 & 10 & 3 & 9 & 12 & 43 \\
\hline 3 & $\begin{array}{l}\text { Balaban } \\
\text { Tekkesi }\end{array}$ & 4 & 4 & 4 & 2 & 8 & 8 & 10 & 9 & 12 & 20 & 81 \\
\hline 4 & $\begin{array}{l}\text { Büyük } \\
\text { Selimiye } \\
\text { Camii }\end{array}$ & 4 & 5 & 5 & 3 & 8 & 8 & 10 & 9 & 12 & 20 & 81 \\
\hline 5 & $\begin{array}{l}\text { Damat } \\
\text { İbrahim } \\
\text { Paşa } \\
\text { Çeşmesi }\end{array}$ & 4 & 4 & 4 & 2 & 4 & 2 & 8 & 9 & 15 & 8 & 60 \\
\hline 6 & $\begin{array}{l}\text { Daye } \\
\text { Kadın } \\
\text { Çeşmesi }\end{array}$ & 3 & 2 & 3 & 1 & 2 & 0 & 8 & 6 & 3 & 8 & 36 \\
\hline 7 & $\begin{array}{l}\text { Doğancıl } \\
\text { ar Parkı } \\
\text { ve } \\
\text { Çeşmesi }\end{array}$ & 5 & 5 & 4 & 3 & 10 & 10 & 6 & 15 & 15 & 20 & 93 \\
\hline 9 & $\begin{array}{l}\text { Harem } \\
\text { semti ve } \\
\text { Otogar1 }\end{array}$ & 3 & 3 & 2 & 3 & 6 & 2 & 6 & 6 & 12 & 8 & 51 \\
\hline 10 & $\begin{array}{l}\text { Hüsrev } \\
\text { Ağa(Esk } \\
\text { i Hamam } \\
\text { Cami) }\end{array}$ & 3 & 3 & 2 & 2 & 2 & 4 & 10 & 6 & 3 & 12 & 47 \\
\hline 11 & $\begin{array}{l}\text { Küçük } \\
\text { İhsaniye } \\
\text { Cami }\end{array}$ & 3 & 5 & 5 & 4 & 8 & 8 & 10 & 12 & 12 & 20 & 87 \\
\hline 12 & $\begin{array}{l}\text { K1z } \\
\text { Kulesi }\end{array}$ & 5 & 4 & 4 & 2 & 10 & 8 & 10 & 9 & 15 & 20 & 87 \\
\hline 13 & $\begin{array}{l}\text { Mihrima } \\
\text { h Sultan } \\
\text { Külliyesi }\end{array}$ & 5 & 5 & 4 & 4 & 8 & 8 & 10 & 12 & 15 & 20 & 91 \\
\hline 14 & $\begin{array}{l}\text { Rum } \\
\text { Mehmet } \\
\text { Paşa } \\
\text { Külliyesi }\end{array}$ & 5 & 5 & 4 & 4 & 10 & 8 & 10 & 12 & 15 & 20 & 93 \\
\hline 15 & $\begin{array}{l}\text { Rüstem } \\
\text { Paşa } \\
\text { Sibyan } \\
\text { Mektebi }\end{array}$ & 4 & 5 & 3 & 2 & 4 & 10 & 10 & 9 & 15 & 20 & 82 \\
\hline 16 & $\begin{array}{l}\text { Sadaka } \\
\text { Taşı }\end{array}$ & 2 & 3 & 0 & 1 & 2 & 4 & 10 & 6 & 15 & 16 & 59 \\
\hline 17 & $\begin{array}{l}\text { Salacak } \\
\text { Fatih } \\
\text { Cami }\end{array}$ & 2 & 1 & 2 & 1 & 2 & 4 & 4 & 3 & 3 & 8 & 30 \\
\hline 18 & $\begin{array}{l}\text { Salacak } \\
\text { Fatih } \\
\text { Çeşmesi } \\
\text { ve Direk } \\
\text { Tașı }\end{array}$ & 2 & 2 & 1 & 0 & 2 & 0 & 6 & 6 & 12 & 8 & 39 \\
\hline
\end{tabular}


Tablo 2 (devam). Kültürel Miras Elemanlarına İlişkin Gözlem Formu Değerlendirmeleri

\begin{tabular}{|c|c|c|c|c|c|c|c|c|c|c|c|c|}
\hline 19 & $\begin{array}{l}\text { Selimiye } \\
\text { Hamamı }\end{array}$ & 3 & 4 & 2 & 0 & 2 & 2 & 6 & 3 & 15 & 8 & 45 \\
\hline 20 & $\begin{array}{l}\text { Selimiye } \\
\text { Kişlası }\end{array}$ & 4 & 5 & 3 & 3 & 8 & 8 & 10 & 12 & 12 & 20 & 85 \\
\hline 21 & $\begin{array}{l}\text { Selmana } \\
\text { ga Cami }\end{array}$ & 2 & 3 & 3 & 1 & 6 & 4 & 10 & 6 & 9 & 16 & 60 \\
\hline 22 & $\begin{array}{l}\text { Silahtar } \\
\text { Mustafa } \\
\text { Ağa } \\
\text { Çeşmesi }\end{array}$ & 1 & 4 & 2 & 0 & 2 & 4 & 6 & 9 & 12 & 8 & 48 \\
\hline 23 & $\begin{array}{l}\text { Sinan } \\
\text { Paşa } \\
\text { Camii ve } \\
\text { çeşmesi }\end{array}$ & 3 & 5 & 4 & 3 & 4 & 8 & 10 & 12 & 12 & 12 & 73 \\
\hline 24 & $\begin{array}{l}\text { III.Ahme } \\
\mathrm{t} \\
\text { Çeşmesi }\end{array}$ & 5 & 5 & 3 & 4 & 10 & 8 & 10 & 9 & 15 & 20 & 89 \\
\hline 25 & $\begin{array}{l}\text { Üsküdar } \\
\text { Meydanı }\end{array}$ & 5 & 5 & 5 & 4 & 10 & 8 & 4 & 12 & 15 & 20 & 88 \\
\hline 26 & $\begin{array}{l}\text { Valide-i } \\
\text { Cedid } \\
\text { Külliyesi }\end{array}$ & 5 & 5 & 4 & 4 & 10 & 8 & 10 & 12 & 12 & 20 & 90 \\
\hline 27 & $\begin{array}{l}\text { Şemsi } \\
\text { Paşa } \\
\text { Külliyesi }\end{array}$ & 5 & 5 & 4 & 4 & 10 & 8 & 10 & 12 & 15 & 20 & 93 \\
\hline 28 & $\begin{array}{l}\text { Şifa } \\
\text { hamamı }\end{array}$ & 2 & 1 & 3 & 0 & 2 & 6 & 8 & 3 & 3 & 4 & 32 \\
\hline 29 & $\begin{array}{l}\text { İsmail } \\
\text { Ağa } \\
\text { çeşmesi }\end{array}$ & 0 & 1 & 1 & 0 & 2 & 0 & 4 & 0 & 9 & 8 & 25 \\
\hline 30 & $\begin{array}{l}\text { Ayşe } \\
\text { Sultan } \\
\text { Çeşmesi }\end{array}$ & 3 & 4 & 1 & 0 & 2 & 4 & 8 & 3 & 9 & 8 & 42 \\
\hline 31 & $\begin{array}{l}\text { İmrahor } \\
\text { Camii }\end{array}$ & 2 & 5 & 4 & 2 & 2 & 6 & 10 & 9 & 12 & 12 & 64 \\
\hline 32 & $\begin{array}{l}\text { İhsaniye } \\
\text { Çeşmesi }\end{array}$ & 2 & 3 & 2 & 2 & 6 & 6 & 2 & 6 & 9 & 8 & 46 \\
\hline
\end{tabular}

Yapılan görsel değerlendirmeye dayalı gözlemler ve puanlama sonucunda puan aralığını 25-93 aralığında olduğu görülmektedir. Doğancılar Parkı ve Çeşmesi, Mihrimah Sultan Külliyesi, Rum Mehmet Paşa Külliyesi, Şemsi Paşa Külliyesi en yüksek puanları alan yapılar arasında yer almaktadırlar. Bu yapılar mevcut kriterleri en iyi şekilde yansıtan kültürel miras varlıklarıdır. Bunun tam tersi olarak İsmail Ağa Çeşmesi, Şifa Hamamı, Salacak Fatih Çeşmesi, Salacak Fatih Camii, Daye Kadın Çeşmesi ise kültürel miras varlıkları arasında en düşük puanları alan yapılardır. Kültürel miras yapıları arasından bir değerlendirme yapıldığında çeşmelerin diğer yapılara istinaden daha bakımsız ve düşük puana sahip olduğu tespit edilmiştir. Görsel değerlendirme açısından düşük puan alan kültürel miras elemanlarının çoğunlukla tarihi çeşmeler olduğu, büyük ölçekli miras elemanlarının nispeten daha iyi korunabildiği ve algılandığı, daha küçük boyutlu miras elemanlarının ise Üsküdar'ın dar ve eğimli sokakları ile artan yapısal yoğunluk arasında algılanamadığı belirlenmiştir. 


\section{PEYZAJ BIYYOGRAFISI}

Üsküdar Meydan ile Selimiye Kışlası arasında Sahilden $1 \mathrm{~km}$ içeride 32 adet kültürel miras alanı yer almaktadır. Bu bölümde miras alanlarına ilişkin peyzaj biyografisi özet olarak sunulmaktadır.

\section{1. Mihrimah Sultan Külliyesi}

Kanûnî Sultan Süleyman tarafından kızı Mihrimah Sultan adına yaptırıldığı kabul edilen külliyenin inşasına 1540'ların ilk yıllarında başlanmış, cami kitâbesine göre 954'te (1547) tamamlanmıştır. Mimar Sinan'ın mimarbaşı olduktan sonra Şehzade Külliyesi ile eş zamanlı olarak inşa ettiği ilk önemli yapı gruplarından biri olan külliye, cami, medrese, sıbyan mektebi, imarettabhâne ve han yanında suyolları, çeşme, hazne ve helâ gibi tesislerden oluşmaktaydı. Ancak sonraki dönemlerde külliyeye iki türbe ve muhtemelen bir çifte hamamla varlı̆̆g gravürlerden tesbit edilebilen ahşap bir kasır ve muvakkithâne eklenmiş, fakat bunlardan imaret-tabhâne, han, kasır ve muvakkithâne zamanla ortadan kalkmış, yakın yıllara kadar hizmet veren çifte hamam ise restorasyon sırasında mağaza haline dönüştürülmüş ve özelliklerini kaybetmiştir [24].

\section{2. III. Ahmet Çeşmesi}

Sultan III. Ahmet Çeşmesi, Üsküdar'da Mihrimah Sultan Camii'nin önündeki İskele Meydanı'nda, Paşa limanı Caddesi'yle Hâkimiyet-i Milliye Caddesinin kesiştiği kavşakta bulunmaktadır [25]. Bir meydan çeşmesi olarak şüphesiz meydanı en çok etkileyen, nirengi noktası oluşturan elemanlardan biri ola günümüze kadar olan süreçte geçirdiği değişikliklerle meydanı da değiştirmiş, şekillendirmiştir. Sultan III. Ahmed Çeşmesi 1932'de bir onarım geçirdiyse de, çeşme 1943-45 yıllarındaki meydan düzenlemesi esnasında çukurda kaldığından, 1955 ’te Sular İdaresi dış kaplamalarının tamamını sökerek yeniden monte etmiştir. Üzerindeki ahşap çatıyı hiç değiştirmeksizin olduğu gibi yukarıya kaldırmıştır. 1987 yılındaki restorasyonda çeşmenin cephelerinde temizlik yapılmış, saçak altlarına yeni nakışlar işlenmiştir. Daha sonraları çeşme 1994 ve 1999 yıllarında onarımlar geçirmiştir [26].

\section{3. Üsküdar Meydanı}

19. yüzyı1 sonlarından itibaren Üsküdar ve Üsküdar Meydanı iskeleden itibaren bir meydanın varlığ1 açıkça görülmektedir. Ancak bu alan çok sık bir şekilde değişikliklere uğramış neredeyse her 10-15 senede bir yeni bir görünüm kazanmıştır. Üsküdar Meydanı, anıtsal yapıları, yerleşim dokusu ve yüklendiği fonksiyonlar ile kendini ifade eden bir mekân olma özelliğine sahiptir [27].

Üsküdar Meydanı'nın ana gövdesini oluşturan bugünkü Demokrasi Meydanı'nın açık bir pazar görünümde olduğunu bilinmektedir. Mihrimah Camii duvarı ile Sultan Ahmet Çeşmesi arasında yer alan tek katlı dükkânlar, diğerinde ise Yeni Valide Camii sebili önündeki satıcılar olduğu eski fotoğraflardan tespit edilmiştir [25].

\section{4. Selman Ağa Camii}

Selman Ağa Camii, İstanbul Boğazı'nın Anadolu yakasında Üsküdar Çarşı Selmanı Park Caddesi ile Hakimiyet-i Milliye Caddesi'nin kesiştiği yerde yer almaktadır. Camii 1500 yıllarında inşa edilmiştir. Camiye ufak bir avludan girilmektedir. Yapımında kesme taş ve tuğla kullanılmıştır [28].

Üsküdar Meydanı'ndaki en eski dini öğe olan Selman Ağa Camii, daha mütevazı ölçekteki boyutuyla, küçük bir çarşı içi cami özelliğindedir. Selman-1 Pak Caddesi'ne açılan kesme taş kemerli avlu kapısının sağ tarafında üst kenarlarında çiniler bulunan üç yüzlü Horhor Çeşmesi ve cami banisi olan Selman Ağa'nın H. 914 tarihli kabri bulunmaktadır. Ayrıca caminin avlusundaki su haznesi ilk yapıldığı dönemden olmayıp, 1256 (1840 M.) tarihinde yapıya eklenmiştir [29]. 


\section{5. Valide-i Cedid Külliyesi}

Lale Devri'ne ait bir eser olan ve yaygınlıkla Yeni Valide Külliyesi olarak bilinen külliye, Üsküdar‘da İskele meydanından çarşı içine girerken asırlık çınar ağaçları içindeki büyük avlulu camisi, caddeye bakan köşeye yerleştirilmiştir. Lale Devri üslubundaki çeşme, sebil ve açık türbesi ile Üsküdar'ın kent içi peyzajının özgün köşelerinden birini oluşturmaktadır. Yeni Valide Külliyesi, ibadet, eğitim, sosyal yardım ve ticari amaçlı dükkânlar ile kent bütünü düşünülerek boyutlandırılmış 16.yüzyılın büyük külliye geleneğini 18.yüzyılın başlarında boyutları küçülerek devam ettiren bir uygulama olarak karşımıza çıkmaktadır [30].

\section{5. Balaban Tekkesi}

Şemsipaşa ve Doğancılar caddelerinin Keresteciler Sokağı ile birleştiği noktada yer almaktadır. Mabet, tahminen 1770 tarihlerinde yapılışından 135-140 sene sonra Sa'diyye Tekkesi olmuştur. Moloz taşından yapılmış olan mabet, 1945 tarihlerinde yıkılmıştır. Kıble duvarı ile sol tarafındaki duvarı hala durmaktadır. Üç kat halindeki bu yapının üst katında şeyh efendinin dairesi bulunmaktaydı. Orta katta ise, mescit olan semahane vardı [29]. Tekke 1829 y1lında Üsküdar'da çıkan yangında büyük hasar görmüştür. Yangında ağır hasar gören tekke, altmış yıl sonra, 1889 yılında yeniden inşa ettirilmiştir. 1925 y1lına kadar faaliyetini sürdürdükten sonra bu tarihte tüm tekkelerin kapatılması ile beraber Balaban Tekkesi'de kapatılarak terkedilmiştir [31].

\section{6. Şemsi Paşa Külliye}

Külliye, Üsküdar Şemsi Paşa semti, Semsi Paşa caddesi üzerinde yer almaktadır. Üsküdar Salacak tarafi ve sahilde olan Camii, İstanbul Boğazı'nın Marmara'ya açıldığı bir noktadadır. Karşısında da Galata Köprüsü ve Haliç yer almaktadır. 1580'de ibadete açılan deniz kıyısındaki bu caminin diğer adı Kuşkonmaz Camiidir. Cami, medrese, çeşme ve türbeden oluşan bu kompleks, Mimar Sinan'ın hayatı boyunca yaptığı en küçük külliyedir. Şemsi Ahmet Paşa adına, 988 (1580) tarihinde, türbe ve cami ile beraber yapılmıştır. Medrese, 1894 zelzelesinde çok zarar görmüştür ve oturulamaz hale gelmiştir [32].

\section{7. Rum Mehmet Paşa Külliyesi}

Üsküdar, Salacak'ta Aziz Mahmut Hüdai Mahallesi, Şemsi Paşa Caddesi üzerinde bulunan cami,1466 yılında Fatih tarafından sadrazam tayin edilen, Rum Mehmet Paşa tarafından yaptırılmıştır. İnşa tarihi 1471-1472 yıllarıdır [33]. Rum Mehmet Paşa Camisi, Üsküdar'da fetihten sonra inşa edilen ilk yapı olma özelliğine sahiptir. Yapının bu özelliği kent strüktürü açısından oldukça önemlidir. Rum Mehmet Paşa külliyesi, dini ve sosyal faaliyetlere cevap veren donatı elemanları ile yapıldığı dönemin büyük ölçekli kompleks yapılarındandır. Üsküdar'ın yol strüktürünün oluşmasında, konut dokusunun şekillenmesinde ve kentin biçimlenmesinde çok önemli bir noktadadır [34].

\section{8. Hüsrev Ağa (Eski Hamam Camii) Camii}

Camii, Şifa Hamamı'nın yanında Rumi Mehmet Paşa Sokağı ile Harem Sahil yolu caddesi arasında yer almaktadır. Kuzeyi Şemsi Paşa Külliye'sine ve Marmaray’a bakmaktadır. Cami hakkında kesin bir inşa tarihi yoktur, tahmini 1520'lerde yapıldığı düşünülmektedir [26]. Camii 1901 yılında onarım çalışması içine alınmıştır. Son devirlerde yapılan müdahaleler sonucu özgün yapı büyük ölçüde değişmiştir. Camii 2016 yılında tekrar restorasyon çalışması içine alınmış ve çalışma günümüzde hala devam etmektedir.

\section{9. Damat İbrahim Paşa Çeşmesi}

Çeşmeler, Osmanlı mimarlı̆̆ının çeşitli dönemlerde sayı ve stil açısından değişiklik gösterse de, III. Ahmet'in saltanat devrini içeren dönemde (1703-1730) çeşmelerde hem nitelik hem nicelik açısından 
büyük bir artış olmuştur. $\mathrm{Bu}$ dönemde çeşme sayısındaki bu yükseliş; nüfusun artmasını, yeni mahallelerin kurulmasını sağlamıştır. Üsküdar semti de, dönemin meşhur sadrazamı Nevşehirli Damat İbrahim Paşa himayesiyle 1729 'da tamamlanan suyolu sayesinde çeşme yaptırma faaliyetinin İstanbul'daki odak noktası olmuş ve bu dönemde Üsküdar pek çok çeşmeye kavuşmuştur [35]. Çeşme 1143 (28 Eylül 1730) günü meydana gelen Patrona Halil isyanında parçalanmıştır. Uncular Sokağı'ndaki Nevşehirli İbrahim Paşa Çeşmesi 1998'de Üsküdar Belediyesince onarılmıştır [29].

\section{10. Şifa Hamamı}

Hamam, Rum Mehmet Paşa Camii civarında olup bu camiye akar olarak yapılmıştır. Cami ile hamamın aynı tarihte yani 1471-72 yıllarında yapıldığ 1 bilinmektedir. Dik, taş bir merdivenden inilmektedir. Burada on metre derinliğinde bir kuyu bulunmaktadır. Bunun 7. metresinde Doğancilar Tepesi'ne doğru uzanan üzeri tonoz çatılı bir dehliz vardır ve kuyunun suyu bu dehlizin derinliklerinden gelmektedir. Daha öncesinde gerek camiin ve gerekse hamamın suyu bu tepe üzerinden gelmekte imiş. Suyolu daha sonra bozulduğundan (1583)'te yaptırılan Atik Valide Suyu verilmiştir. İlk suyun geldiği yer hâlâ Mehmet Paşa Değirmeni Sokağı adıyla anılmaktadır.12 Eylül 1860 tarihli bir gazete ilânından Eski Hamam'ın şahıs eline geçmiş olduğu anlaşılmaktadır. Ayrıca hamamın 1885-86'da tamir olduğu bilinmektedir [36].

\section{11. İsmail Ăga Çeşmesi}

Çeşme, Şemsipaşa semtinde ve eski Medrese Sokağı, şimdiki Eşref Saat Sokağı ile Şemsipaşa Caddesi'nin birleştiği köşededir. Etrafında birçok tarihi eserler vardır. Çeşmenin hemen arkasında Rum Mehmet Paşa Camii ve medresesi, sağ tarafında Eski Hamam'ın külhan kapısı bulunmaktadır [37]. Yapının kaş kemeri üzerindeki kitabeden İsmail Ağa tarafından 1703 tarihinde yapıldığı anlaşılmaktadır. Çeşme tamamen kesme taştan yapılmıştır.

Köşeleri pahlanmıştır ve ince sütunlar yerleştirilmiştir. Çeşmenin üstünde dairesel motifler bulunmaktadır. Çeşme 1975 yılında harap duruma gelmiştir. 1976 y1lında aslına uygun bir şekilde restore edilmiştir [29].

\section{12. Ayazma Külliyesi}

18. yüzyılda, Sultan III. Mustafa tarafından annesi Mihrişah Emine Sultan ve kardeşi Şehzade Süleyman adına yaptırılan camii, Şemsipaşa-Salacak semtleri arasında Boğaz'a hâkim bir tepede kurulmuştur. Kızkulesi karşısındaki hâkim tepede yer alan cami 1754-60 seneleri arasında inşa edilmiş olup cami, sıbyan mektebi, hamam, çeşme ve su yapıları ile bir külliye teşkil etmektedir [38]. Ayazma külliyesi; cami, sıbyan mektebi, hamam ve dükkânlardan oluşturduğu bir yap1 grubudur. Fakat günümüze bakıldığında dükkânlar ve hamamı yıkılmış, sıbyan mektebi geçirdiği değişimlerle beraber Ayazma İlkokulu olarak görevini sürdürmekte, cami ise sağlam durumda olup, restorasyon süreci devam etmektedir [26].

\section{13. Rüstem Paşa Sıbyan Mektebi}

Mektep, İmrahor semtinde Doğancılar Caddesi ile Hafız Ali Paşa sokağının birleştiği yerdedir. Karşısında İmrahor Camii, caminin yanında Başkadın Çeşmesi ve Ayşe Sultan Çeşmesi vardır. Doğancılar Caddesi'ne açılan bir kapıdan avluya girilmektedir. Mektebin banisi Mihrimah Sultan'ın eşi Rüstem Paşa'dır. Mektep 1897 yılında onarılmıştır. Bugün bina sağlam olarak bir vakıf tarafından kullanılmaktadır [26]. 


\section{14. Ayşe Sultan Çeşmesi}

Çeşme 1598-1599 yıllarında Ayşe Sultan tarafından yaptırılmıştır. Çeşme ikiyüzlü ve iki hanelidir. Çeşmenin üstü çatısızdır. Ön cephesi mermerdendir. Yalın bir tasarımı vardır. Üst bölümünde yaldızlı kitabesi bulunmaktadır. Sivri kemerli bir niş görülmektedir. Sivri kemerin iki yanında altın yaldızlı birer rozet görülmektedir [37]. Doğancılar Caddesi ile Öğdül Sokağı'nın birleştiği yerde ve sokağın sağ köşesindedir. Arkasındaki iki katlı Ayşe Sultan Celveti Tekkesi bugün mevcut değildir. Karşısında, babası Rüstem Paşa Sıbyan Mektebi, sol ilerisinde ise İmrahor Camii ile Başkadın Çeşmesi ve İmrahor Camii Mezarlığı bulunmaktadır. Mezarlık günümüzde arsa halinde olup içindeki taşların bir kısmı yok olmuştur [26].

\section{15. İmrahor Camii}

İmrahor Camii veya Mirahur Camii; İstanbul Boğazı'nın Anadolu yakasında Üsküdar Aziz Mahmut Hüdai Mahallesi'nde 1598 tarihlerinde inşa edilmiştir. Sadrazam Koca Sinan Paşa'nın imrahoru olan Mehmet Ağa tarafından yaptırılmıştır. Yapımına 1597 yılında başlanan cami, bir yıllık inşaat sürecinden sonra 1598 yılında ibadete açılmıştır [26]. Caminin bahçesinde anıtsal çınar ağacı yer almaktadır. Çınar ağacı oldukça yaşlıdır. Anıt ağaç olarak nitelenen bu doğu çınarının gövdesinin çevresi yaklaşık 6 metre ve çap1 2 metredir. 200 yaşı üzerinde olduğunu tahmin etmektedirler. Ağacın içi tamamen boşalmış durumdadır[39].

\section{16. Başkadın Meydan Çeşmesi}

Çeşme, Doğancılar Caddesi üzerinde ve bu caddenin Öğdül Sokağ1 ile birleştiği Küçük İmrahor Meydanı'ndadır. Tam karşısında Mimar Sinan yapısı, Sadrazam Rüstem Paşa Mektebi, sol tarafında İmrahor Camii ile çeşmenin su terazisi, arkasında ulu bir çınar ağacı ve mezarlık vardır. Sağ gerisinde ise Ayşe Sultan Çeşmesi bulunmaktadır [37]. 1728-1729'da yaptırılan büyük hazneli çeşme kesme taştan yapılmış yüzü ise mermer ile kaplanmıştır. Lale Devri'nde yaptırılan bu güzel görünümlü çeşmenin ayna taş üzerinde lale kabartmaları görülmektedir [29]. Sıbyan Mektebinin tam karşısında bulunan Başkadın Meydan Çeşmesi 1985 Kasım ayında Taşınmaz ve Kültür Varlıkları İstanbul Bölge Kurulu kararı ile yıktırılmış, yeri ve yönü değiştirilerek sadece ön cephesi yeniden inşa edilmiştir. Sadece eski çeşmenin ön cephesi aslına uygun olarak giydirilmiş, arkasındaki eski su haznesi yok edilerek yerine abdest alınması amaciyla musluklar konulmuştur. Günümüzde çeşme; meydan çeşmesi olma özelliğini kaybetmiştir [40].

\section{17. Salacak Fatih Cami}

Salacak’ta Salacak İskele arkası Sokağ 1 üzerinde yer almaktadır. Salacak Camii adıyla da bilinmektedir. Caminin ilk yapım tarihi olarak Fatih Sultan Mehmet Devri (1453-1481) gösterilmektedir. Fatih Sultan Mehmet tarafından yaptıılan camiin yapımına 1453 yılında başlanmış ve aynı yıl ibadete açılmıştır [27]. Üsküdar'da ilk inşa olunan cami Salacak Fatih Camii'dir. Salacak Fatih Camii, Anadolu Osmanlı mimarisi özelliklerini taşımaktadır. Zaman içerisinde çeşitli nedenlerle harap olan cami, 1753 yılında ilk olarak Birinci Mahmut tarafından onarılmış ve daha sonraları ise çeşitli zamanlarda onarımlar geçirmiş̧tir. Camii ayrıca 1894 depreminde de zarar görmüş ve harap olmuştur [41].

\section{18. Silahtar Mustafa Ă̆a Çeşmesi}

Üsküdar Salacak’ta, Sinan Paşa Mahallesi’ndeki çeşme, Sultan 2. Süleyman'ın silahtarlarından Mustafa Ağa tarafından yaptırılmış. Çeşme bakımlı ve temiz bir görünüme sahiptir ancak suyu akmamaktadır. Çevresi peyzaj tasarımı ile desteklenmiştir [26]. 


\section{19. Sinan Paşa Camii ve Çeşmesi}

Camii; Üsküdar'da Doğancılar ile Salacak İskelesi arasında inşa edilmiştir. Üsküdar Kaymakamlığ1 binasının arkasındaki semtte yer almaktadır. Cami, hamam, çeşme ve bütün bir mahalle, Yemen Fatihi Sinan Paşa tarafından yaptırılmıştır [42]. Caminin kitabesi günümüze gelmediğinden hangi tarihte yaptırıldı ğı tam belli değildir. Fakat caminin birimlerine ait vakıflar yapılış tarihlerinin 1582-1593 yılları arasında olduğunu kaydetmiştir. Dolayısıyla cami ve mahalle de bu tarihler arasında yaptırılmıştır. Caminin arkasında bulunan hamamın iki kapısı olup çıkmaz sokak tarafındaki külhan kapısı, topraklı sokak tarafındaki ise cümle kapısı olarak kullanılmıştır. Hamam 1918' deki büyük Üsküdar yangınında 230 bina ile cami birlikte yanmış ve harap olmuştur [43].

\section{20. Doğancılar Parkı ve Çeşmesi}

Günümüzde Halk Caddesi ve Doğancılar Caddesi tarafından çevrelenen Doğancılar Parkı, tarihsel süreçte Doğancılar Meydanı adıyla anılmıştır. Doğancılar çevresi Osmanlı devrinde Saray teşkilatı içinde av kuşlarını yetiştirip, padişahla birlikte ava giden Çakırcı (Doğan Kuşlarını yetiştiren) birliğinin yerleştiği yer olarak bilinmektedir. Bölge adını da buradan almıştır. Yerleşimin gelişmesiyle birlikte çevresine dini yapılar ve değişik kamu yapıları yapılmış ancak Doğancılar Meydanı açık mekân olarak işlevini halen devam ettirmektedir. Park yapımına kadar haftanın bir günü, pazaryeri olarak kullanılmıştır [27] Doğancılar Meydanı; Üsküdar'ın yedi tepesinden biri üzerinde olduğundan gerek Marmara Denizi'ne ve gerekse kent merkezine bakan güzel bir manzaraya sahiptir [29].

\section{21. İhsaniye Camii}

İhsaniye Camii; İstanbul Boğazı'nın Anadolu yakasında Üsküdar İhsaniye Mahallesi eski Sultaniye, daha sonra Çatmacılar, Dr.Sıtkı Özferendeci Sokağı ile Neyzenbaşı Halil Can Sokağı' nın çevrelediği yapı adasında yer almaktadır. Caminin her iki sokağa açılan kapıları yer almaktadır [44]. Padişah tarafından semte cami, evler, dükkânlar ve çarşıdan oluşan bir yerleşim yeri kurulmuştur. Bu nedenle semtin ve caminin adı İhsaniye olarak anılmaya başlanılmıştır. Cami 1860'ta bir yangın geçirmiş ve zarar görmüştür. Kâgir duvarlı cami, ahşap kırma çatılı ve kiremit örtülüdür. Caminin sağ tarafında bulunan minaresi ise kare şeklindeki taş kaide üzerine tuğladan inşa edilmiştir. Şerefe ve minare külahı taştandır [27].

\section{22. Harem Semti ve Harem Otogarı}

İstanbul'u Kapısı Anadolu yakasındaki Harem Otogarı 1970 yılında hizmete girmiştir. Avrupa'daki Esenler, diğer adıyla Büyük İstanbul Otogarı'yla birlikte yıllarca ulaşım yükünü sırtlayıp, şehre ayak basanların ilk durağı olmuştur. Anadolu'dan karayolu ile gelen trafiğin deniz yoluyla Avrupa yakasına aktarılması nedeniyle Harem'de yer seçen Harem Otogarı, köprülerin yapılmasından ve kent içi trafik düzenlemesinin ardından atıl duruma gelmiştir. Onaylanan 1/5000 ölçekli Harem Bölgesi ve Haydarpaşa Liman ve Geri Sahası Nazım İmar Planı kapsamında, bulunduğu yerden kaldırılması kararı alınmıştır. Kentteki otogar ihtiyacının “cep otogarları” ile karşılanması öngörülmüştür [45].

\section{23. Selimiye Hamamı}

Hamam, Selimiye Hamamı Sokağı, Selimiye Camii Sokağı, Şerif Kuyusu Sokağı ve Selimiye Kışlası Caddesi ile çevrelenen yapı adasında yer almaktadır.1217 yılında yapımına başlanan hamam 1218 yılında tamamlanmıştır. Hamamın bulunduğu noktaya yapılmasının asıl amacı çarşı içinde olmasıdır [46]. III. Selim tarafından 1789-1807 yılları arasında; muvakkithane, çeşme ve bir sebil ile birlikte inşa edilen Selimiye Camii, Üsküdar'da Selimiye Kışlasının karşısındadır. Dört yönden giriş verilmiş geniş bir avlunun ortasında inşa edilen Camii, döneminde etkisiyle batılı mimari tarzın etkisinde kalmıştır. Ayrıca; inşa edildiği ilk yıllarda cami minaresi çok kalın görüldüğü için minare taşları yontulup 
inceltilmeye çalışılmış; 1823 yılında şiddetli bir lodos firtınasında minarelerden biri tamamen, diğeri k1smen çökmüş ve daha sonra bu minareler restore edilmiştir [47].

\section{24. Selimiye Kışlası}

Kışla, III. Selim tarafından 1800-1801 tarihleri arasında, bir yıldan kısa bir sürede, Üsküdar' daki Kavak Sarayı'nın arsasına yaptırılmıştır. Kışla iki katlıdır ve 29 odadan meydana gelmektedir. Kiremit kaplamalı kırma çatı ile örtülüdür. Kışla, tek blok biçiminde değil, çevresindeki hizmet binaları ile birlikte, yapılar topluluğu şeklinde tasarlanmıştır. Silahhane, ahırlar, odun deposu gibi çeşitli servis birimleri, ana kütlenin dışında yer almaktadır. Hastane, mutfak, çamaşırhane gibi birimler, kışlanın doğusunda ve batısında olmak üzere ikişer tane yapılmıştır. Bu yerleşim düzeninde, geometrik olmasa da kurgusal simetri bulunmaktadır. Kışlanın deniz tarafında talim meydanı yer almaktadır [46].

\section{25. Kız Kulesi}

Üsküdar'ın önemli bir parçası da tarih boyunca hem İstanbul'un hem de Üsküdar'ın simgesi olan Kız Kulesi'dir. Kulenin, dönemler içinde işlevi zaman zaman değişmiştir. Geçmiş dönemlerde deniz kıyısında kurulan şehirlerde liman girişlerinin korunmasında ön bölgede bir kule inşa edilmekteydi. Kız Kulesi de bu anlamda İstanbul'un önünde önemli bir yere sâhiptir. Bizans döneminde, Akdeniz'den Karadeniz'e geçen gemilerden geçiş vergisi ya da haraç alınması işleminde kontrol merkezi olarak kullanılmıştır. Şehrin fethinden sonra Osmanlı döneminde onarımdan geçirilmiş, kare plânlı bir kule olarak yükselerek üst bölümüne ahşap bir köşk şeklinde bir kısım eklenmiştir. Bu hâliyle boğaz ve liman güvenliğini sağlayan bir fener kulesi görevi sağlamıştır. XVIII. Yüzyıl da ise kısa süreliğine hapishane olarak kullanılmıştır. Kulenin mimari görünümü XIX. yüzyıl başlarında değiştirilerek barok tarzda bir fener kulesi olarak bugünkü şeklini almıştır [48]. II. Mahmut döneminde (1832) onarım geçirmiş ve bugünkü halini almıştır. Kule, tarihi süreçte belirli aralıklarla tamir görmüştür. Fatih zamanında yeniden inşa edildiğini gördüğümüz kule, 1509 depreminde İstanbul'un diğer önemli yapılarıyla birlikte ağır şekilde hasar görmüştür [27]. Son olarak ise 2000 yllında onaylanan projesine uygun olarak restorasyonu gerçekleştirilmiştir. Günümüzde lokanta, kafe ve turistik gezi noktası olarak kullanılmaktadır.

Yukarıda anlatılan, tarihi ve değişim süreçleri verilen kültürel miras varlıklarından bazıları aşağıda verilmiştir.

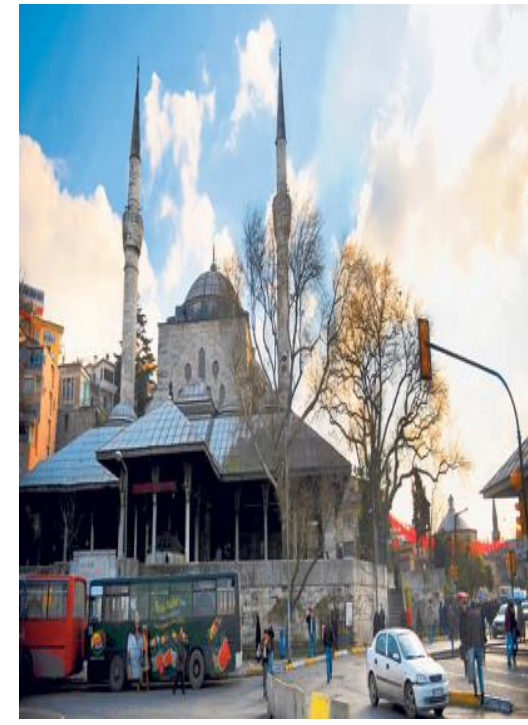

Şekil 3. Mihrimah Sultan Külliyesi

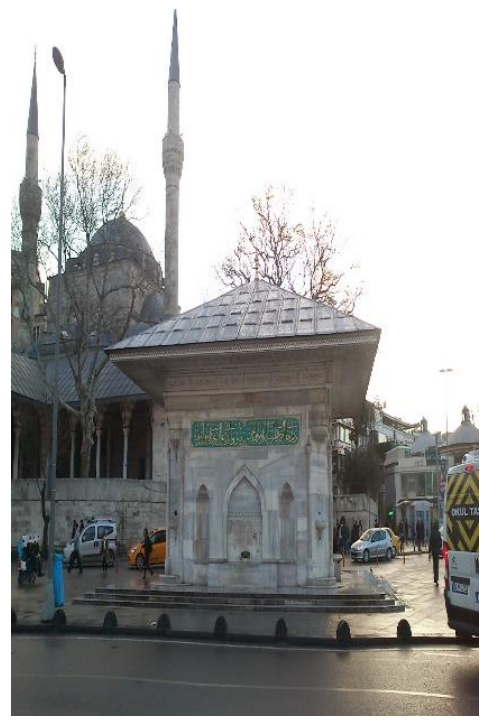

Şekil 4. III.Ahmet Çeşmesi

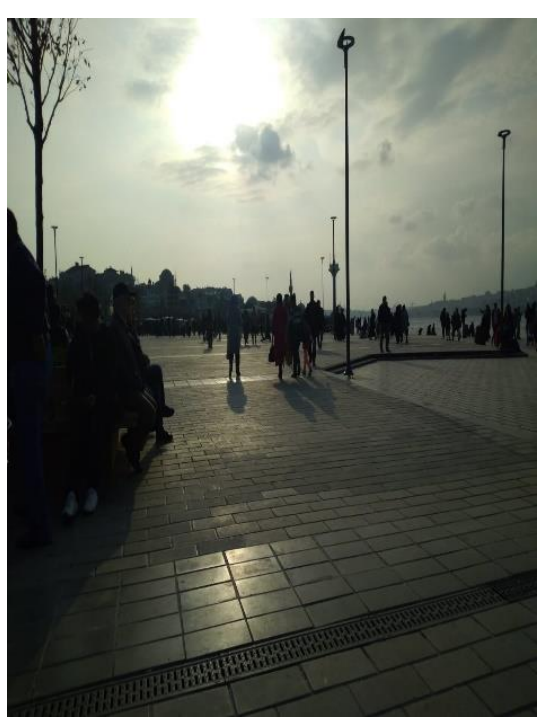

Şekil 5. Üsküdar Meydanı 


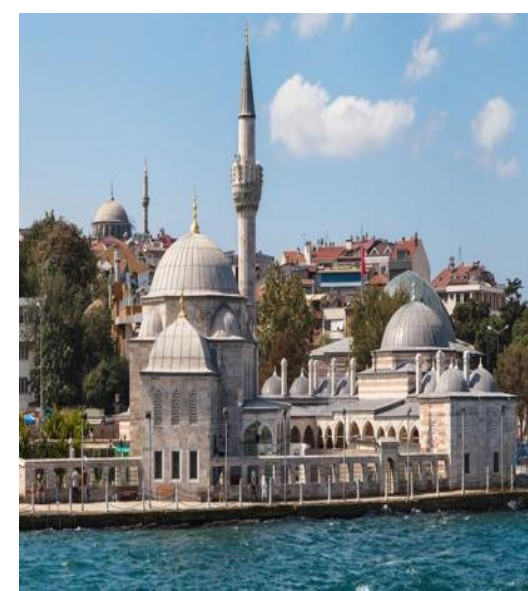

Şekil 6. Şemsi Paşa Külliyesi

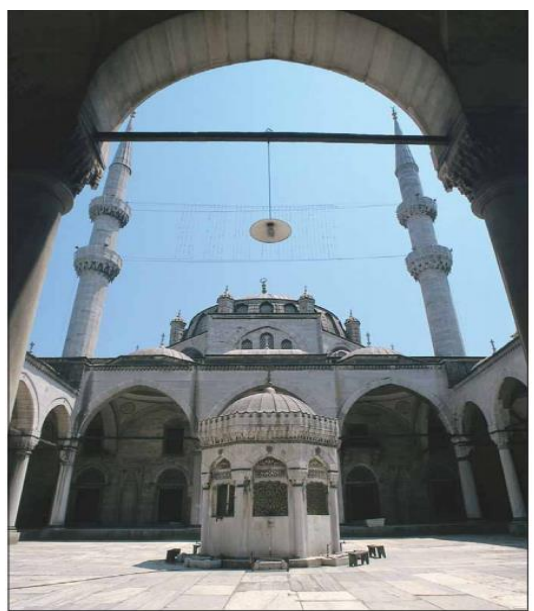

Şekil 9. Ayazma Külliyesi

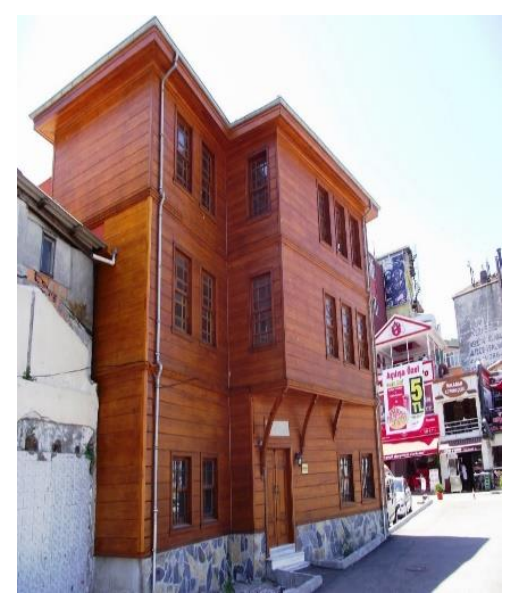

Şekil 7. Balaban Tekkesi

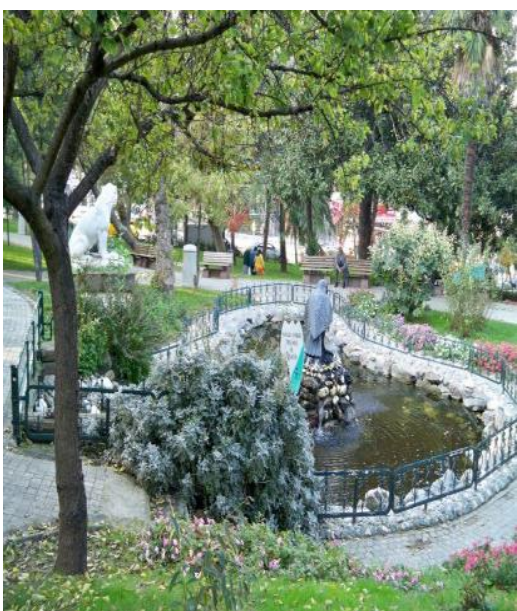

Şekil 10. Doğancılar Parkı

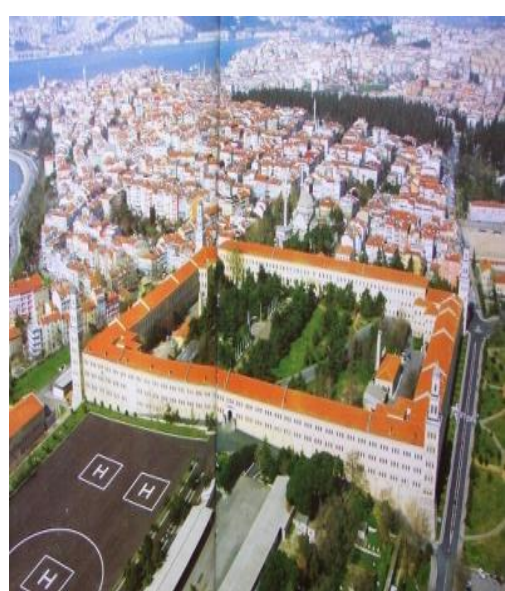

Şekil 8. Selimiye Kışlası

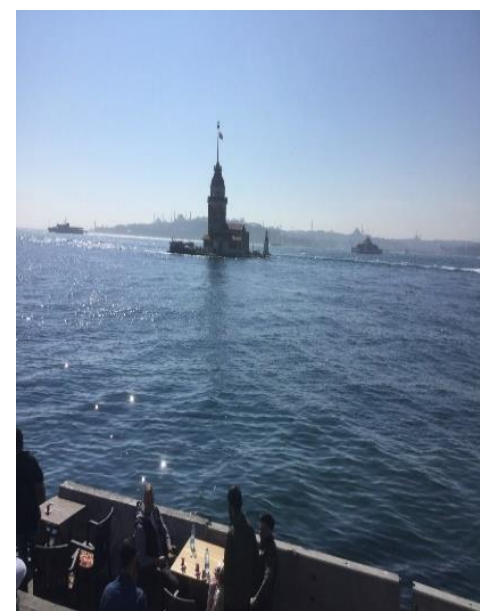

Şekil 11. Kız Kulesi

\section{TARIHI ÇEVRELERDE YAŞAYAN HALKIN KENTSEL KÜLTÜREL MİRAS ELEMANLARINA İLIŞKINN FARKINDALIĞININ DEĞERLENDİRILMESİ}

Katılımcı bakış açısı ile çalışma alanı kentsel kültürel miras elemanlarına ilişkin kent halkı farkındalığının değerlendirilmesi amacı ile anket geliştirilmiş ve uygulanmıştır. Katılımcıların sosyodemografik özelliklerine ilişkin sıklık ve yüzde analizleri Tablo 2'de belirtilmektedir.

Tablo 3. Ankete katılanların Sosyo-Demografik Özelliklerine İlişkin Sıklık ve Yüzde Analizleri

\begin{tabular}{llll}
\hline Özellik & & Sayı & Yüzde \\
\hline \multirow{3}{*}{ Cinsiyet } & Kadın & 186 & 46,5 \\
\cline { 2 - 4 } & Erkek & 214 & 53,5 \\
\cline { 2 - 4 } & Toplam & 400 & 100 \\
\hline \multirow{3}{*}{ Medeni Durum } & Evli & 223 & 55,8 \\
\cline { 2 - 4 } & Bekar & 177 & 44,3 \\
\cline { 2 - 4 } & Toplam & 400 & 100 \\
\hline \multirow{5}{*}{ Yaşınız } & $12-18$ & 23 & 5,8 \\
& $19-25$ & 66 & 16,5 \\
\cline { 2 - 4 } & $26-35$ & 110 & 27,5 \\
\cline { 2 - 4 } & $36-45$ & 101 & 25,3 \\
\hline & $46-65$ & 68 & 17 \\
\hline
\end{tabular}


Tablo 3 (devam). Ankete katılanların Sosyo-Demografik Özelliklerine İlişkin Sıklık ve Yüzde Analizleri

\begin{tabular}{|c|c|c|c|}
\hline & 65 ve üstü & 32 & 8 \\
\hline & Toplam & 400 & 100 \\
\hline \multirow{7}{*}{ Eğitim Durumu } & Okuryazar değil & 8 & 2 \\
\hline & İlköğretim & 105 & 26,3 \\
\hline & Lise & 153 & 38,3 \\
\hline & Önlisans & 47 & 11,8 \\
\hline & Lisans & 73 & 18,3 \\
\hline & Lisansüstü & 14 & 3,5 \\
\hline & Toplam & 400 & 100 \\
\hline \multirow{6}{*}{ Mesleğiniz } & Öğrenci & 58 & 14,5 \\
\hline & Memur & 70 & 17,5 \\
\hline & İşçi & 79 & 19,8 \\
\hline & Özel sektör & 98 & 24,5 \\
\hline & İşsiz & 95 & 23,8 \\
\hline & Toplam & 400 & 100 \\
\hline \multirow{6}{*}{ Üsküdar'da yaşama süresi } & $1-5$ y1l & 64 & 16 \\
\hline & $5-15$ y1l & 117 & 29,3 \\
\hline & $16-30$ y1l & 130 & 32,5 \\
\hline & $31-45$ y1l & 53 & 13,3 \\
\hline & 45 yıldan fazla & 36 & 9 \\
\hline & Toplam & 400 & 100 \\
\hline \multirow{6}{*}{ Hanenizin Aylık Geliri } & Asgari ücret & 42 & 10,5 \\
\hline & $1400-2500 \mathrm{TL}$ & 122 & 30,5 \\
\hline & $2500-4500 \mathrm{TL}$ & 174 & 43,5 \\
\hline & $4500-7000 \mathrm{TL}$ & 52 & 13 \\
\hline & 7000 TL ve üstü & 10 & 2,5 \\
\hline & Toplam & 400 & 100 \\
\hline \multirow{27}{*}{ Oturduğunuz Mahalle Adı } & Ahmediye Mah. & 12 & 3 \\
\hline & Altunizade Mah. & 18 & 4,5 \\
\hline & $\begin{array}{l}\text { Aziz Mahmud Hüdai } \\
\text { Mah. }\end{array}$ & 9 & 2,3 \\
\hline & Bahçelievler Mah. & 11 & 2,8 \\
\hline & Barbaros Mah. & 14 & 3,5 \\
\hline & Beylerbeyi Mah. & 14 & 3,5 \\
\hline & Bulgurlu Mah & 8 & 2 \\
\hline & Burhaniye Mah. & 8 & 2 \\
\hline & Cumhuriyet Mah. & 11 & 2,8 \\
\hline & Çengelköy Mah. & 14 & 3,5 \\
\hline & Ferah Mah. & 13 & 3,3 \\
\hline & Güzeltepe Mah. & 10 & 2,5 \\
\hline & İcadiye Mah. & 15 & 3,8 \\
\hline & Kandilli Mah. & 11 & 2,8 \\
\hline & Kisıklı Mah. & 13 & 3,3 \\
\hline & Kirazlitepe Mah. & 9 & 2,3 \\
\hline & Kuleli Mah. & 15 & 3,8 \\
\hline & Kuzguncuk Mah. & 14 & 3,5 \\
\hline & Küçük Çamlıca Mah. & 6 & 1,5 \\
\hline & Küçuksu Mah. & 5 & 1,3 \\
\hline & Kaplica Mah. & 7 & 1,8 \\
\hline & $\begin{array}{l}\text { Mehmet Akif Ersoy } \\
\text { Mah. }\end{array}$ & 11 & 2,8 \\
\hline & Mimar Sinan Mah. & 23 & 5,8 \\
\hline & Murat Reis Mah. & 9 & 2,3 \\
\hline & Salacak Mah. & 24 & 6 \\
\hline & Selamiali Mah & 13 & 3,3 \\
\hline & Sultantepe Mah. & 21 & 5,3 \\
\hline
\end{tabular}


Tablo 3 (devam). Ankete katılanların Sosyo-Demografik Özelliklerine İlişkin Sıklık ve Yüzde Analizleri

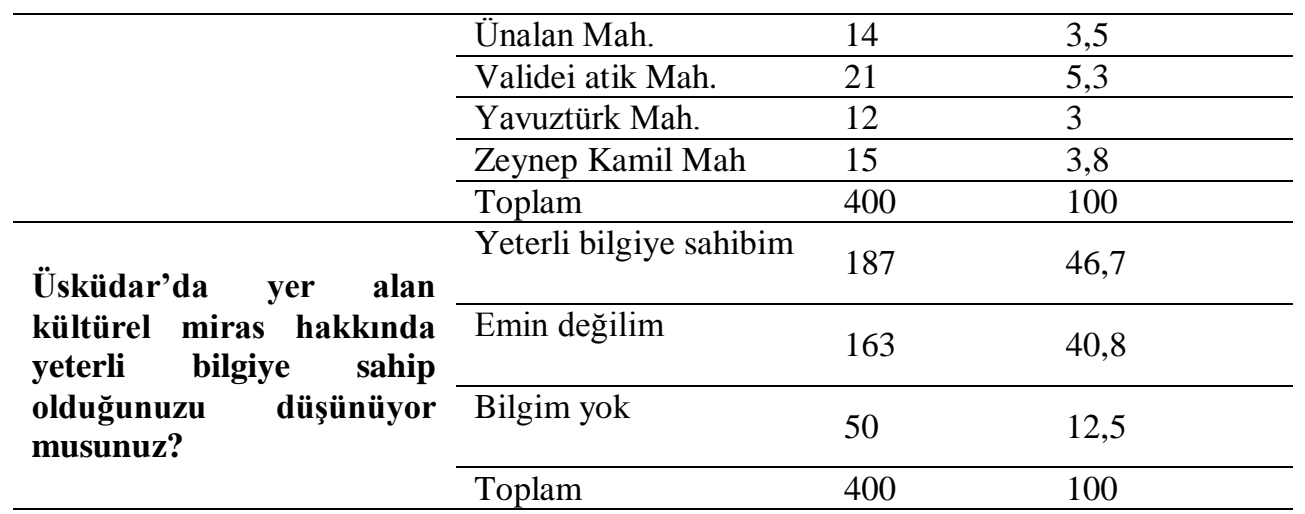

Tablo 3 değerlendirildiğinde, ankete katılanların cinsiyet ve medeni durum özellikleri açısından dağılımlarında eşitlik nispeten yakalanmıştır. Katılımcıların yaş dağılımı çoğunlukla 26-45 yaş aralığında bulunmaktadır. Ankete katılanların çoğunluğu ilköğretim ve lise eğitim düzeyindedir. Ankete katılanların çoğunluğu özel sektörde çalışmaktadır. Katılımcıların çoğunluğu 16-30 yıl aralığında alanda yaşadıklarını, orta düzeyde gelire sahip olduklarını belirtmişlerdir. Çalışma alanı tüm Üsküdar halkı, İstanbul halkı ve turistlerin sıkça ziyaret ettiği bir alan olup, tesadüfi örnekleme yolu ile yapılan ankete Üsküdar İlçesi'ne bağlı 33 mahalleden katılım sağlanabilmiştir. Ankete katılan 400 katılımcıdan 187'si alanda yer alan kültürel miras hakkında yeterli bilgiye sahip olduklarını düşünmektedir.

Tablo 3'te çalışma alanında yaşayan halkın kentsel kültürel miras alanlarına ilişkin farkındalık düzeylerini ölçmek amacıyla yöneltilen önermelere verdikleri yanıtlara ilişkin ortalama ve standart sapma değerleri yer almaktadır. (Kesinlikle katılıyorum: 5, kesinlikle katılmıyorum: 1).

Tablo 4. Ankete katılanların Kültürel Miras Elemanlarına İlişkin Farkındalıklarına Yönelik Ortalama ve Standart Sapma Değerleri

\begin{tabular}{|c|c|c|c|}
\hline $\begin{array}{l}\text { Önerme } \\
\text { No }\end{array}$ & Önerme & Ortalama & $\begin{array}{l}\text { Standart } \\
\text { Sapma }\end{array}$ \\
\hline 1 & $\begin{array}{l}\text { Son dönemde yapılan projeler, } \\
\text { Üsküdar'ın kültürel mirasını olumsuz } \\
\text { etkilemektedir. }\end{array}$ & 3,0125 & 1,13161 \\
\hline 2 & $\begin{array}{l}\text { Kentleşme ve yapılaşma kültürel miras } \\
\text { ile uyumludur. }\end{array}$ & 2,9650 & 1,06377 \\
\hline 3 & $\begin{array}{l}\text { Kültürel mirasın yok olma tehlikesi } \\
\text { vardır. }\end{array}$ & 3,1500 & 1,12279 \\
\hline 4 & Üsküdar halkı kültürel mirası önemsiyor & 3,6150 & 1,10899 \\
\hline 5 & $\begin{array}{l}\text { Kültürel mirasın çevresindeki değişim } \\
\text { görsel kirlilik yaratmaktadır. }\end{array}$ & 3,3300 & 1,09274 \\
\hline 6 & $\begin{array}{l}\text { Üsküdar kıyı bandı kültürel turizmde } \\
\text { turistlerin geldiği bir alandır }\end{array}$ & 3,7675 & 1,08692 \\
\hline 7 & $\begin{array}{l}\text { Üsküdar'da koruma bölgeleri ve } \\
\text { kullanım bölgeleri belirsizdir. }\end{array}$ & 2,9125 & 1,08295 \\
\hline 8 & $\begin{array}{l}\text { Üsküdar' da bulunan kültürel miras } \\
\text { alanları yaşantımda önemli bir yere } \\
\text { sahiptir. }\end{array}$ & 3,9175 & ,89313 \\
\hline 9 & $\begin{array}{l}\text { Kültürel miras alanları bulunduğu için } \\
\text { Üsküdar'da yaşıyorum }\end{array}$ & 3,3225 & 1,23178 \\
\hline
\end{tabular}


Tablo 4 (devam). Ankete katılanların Kültürel Miras Elemanlarına İlişkin Farkındalıklarına Yönelik Ortalama ve Standart Sapma Değerleri

\begin{tabular}{|c|c|c|c|}
\hline 10 & $\begin{array}{l}\text { Kültürel mirasın yeterince korunduğunu } \\
\text { düşünüyorum }\end{array}$ & 3,1925 & 1,12410 \\
\hline 11 & $\begin{array}{l}\text { Üsküdar'da yer alan kültürel miras } \\
\text { alanları dünya miras listesine alınmalıdır. }\end{array}$ & 4,1825 & ,97033 \\
\hline 12 & $\begin{array}{l}\text { Üsküdar ve çevresinin zaman içerisinde } \\
\text { daha güzelleştiğini düşünüyorum }\end{array}$ & 3,6300 & 1,14077 \\
\hline 13 & $\begin{array}{l}\text { Üsküdar'ın kentsel gelişim sürecinde } \\
\text { kültürel miras göz önünde } \\
\text { bulundurulmuştur. }\end{array}$ & 3,2000 & 1,15687 \\
\hline 14 & $\begin{array}{l}\text { Üsküdar'ın dışardan göç alması ve yaşam } \\
\text { şeklindeki değişimler kültürel mirasa } \\
\text { zarar vermiştir. }\end{array}$ & 3,3100 & 1,16288 \\
\hline 15 & $\begin{array}{l}\text { Üsküdar'da Belediyeler ve kamu } \\
\text { kurumları kültürel mirasın korunmasına } \\
\text { yönelik yeterli düzeyde çalışma } \\
\text { yapmaktadır. }\end{array}$ & 3,1150 & 1,11350 \\
\hline 16 & $\begin{array}{l}\text { Üsküdar'da kültürel miras bilinci } \\
\text { oluşturulmasında çocukların eğitimi } \\
\text { önemlidir. }\end{array}$ & 4,2600 & ,94585 \\
\hline 17 & $\begin{array}{l}\text { Üsküdar'da kültürel miras alanlarına } \\
\text { günlük ziyaretçi sayıları kısıtlanmalıdır. }\end{array}$ & 2,2375 & 1,18304 \\
\hline 18 & $\begin{array}{l}\text { Üsküdar'da kültürel miras alanlarını } \\
\text { tanıtan ve yönlendiren tabela eksikliği } \\
\text { vardır. }\end{array}$ & 3,1750 & 1,09881 \\
\hline 19 & $\begin{array}{l}\text { Üsküdar'da kültürel mirasın } \\
\text { korunmasında halk katılımı } \\
\text { arttırılmalıdır. }\end{array}$ & 4,1050 & ,95460 \\
\hline 20 & $\begin{array}{l}\text { Üsküdar' da kültürel miras ve kentsel } \\
\text { yaşam bütünleştirilmelidir. }\end{array}$ & 4,0600 & ,96370 \\
\hline 21 & $\begin{array}{l}\text { Üsküdar'da devam eden inşaat ve kazı } \\
\text { çalışmaları turistlerin gelişini } \\
\text { azaltmaktadır. }\end{array}$ & 3,5425 & 1,09599 \\
\hline 22 & $\begin{array}{l}\text { Kültürel miras alanlarını ziyaret ücretli } \\
\text { olmalıdır. }\end{array}$ & 1,9575 & 1,13530 \\
\hline
\end{tabular}

Tablo 4'te Ankete katılanların çalışma alanında ve yaşadıkları semtte bulunan kültürel miras elemanlarına ilişkin farkındalıkları değerlendirildiğinde ziyaretçi taşıma kapasitesini kontrol altına almak amaçlı bir öneri olan ziyaret ücreti uygulamasına kesinlikle katılmadıklarını ve ziyaretçi sayılarının kısıtlanmaması gerektiğini belirtmektedirler. Ayrıca katılımcılar, kültürel bilincin gelişmesinde yeni neslin eğitiminin önemli olduğunu, halkın katılımı sürecinin işletilmesi gerektiğini, devam eden kazı ve inşaat çalışmalarının turist ziyaretini olumsuz etkilediğini, halkın kültürel mirası önemsediğini ve yaşantılarında önemli bir yere sahip olduğunu ifade etmişlerdir.

Çalışmanın bu bölümünde elde edilen bir diğer önemli sonuç ise çalışma alanında yaşayan halkın uzun süredir alanda yaşamalarına rağmen, "çalışma alanına ilişkin koruma-kullanım bölgelerinin belirlenmiş olup olmadığı, göç almasının kültürel mirasa zarar verip vermediği, kültürel mirasın yok olma tehlikesi ile karşı karşıya olup olmadığı, kentleşme çalışmaları ile kültürel miras dokusunun uyuma sahip olup olmadığı konusunda" kararsız olduklarını belirtmişlerdir. 


\section{E. PAYDAŞ GÖRÜŞMELERİ VE MEVZUAT}

Çalışma kapsamında kültürel miras elemanlarının korunması ve sürdürülebilirliğinin sağlanması konusunda paydaşlar olarak İstanbul Büyükşehir Belediyesi, Üsküdar Belediyesi, Üsküdar Kaymakamlığı, Çevre ve Kültür Değerlerini Koruma ve Tanıtma Vakfı, Tarih Vakfi, Üniversitelerde görev yapan ilgili uzmanlar ile 2017-2019 yılları arasında ucu açık sorulardan oluşan sözlü görüşmeler yapılmıştır. Yapılan görüşmeler temel bilgiler sağlamak amacı ile konunun akışına göre gelişme göstermiştir. Tüm paydaş görüşleri kısaca özetlendiğinde; kamu- sivil toplum ve akademisyenlerin kentsel kültürel mirasın korunması, kentleşme çalışmalarında kültürel odaklı yaklaşımların benimsenmesi gerektiği, katılımcı bir anlayışla projelerin hazırlanması konularında ortak görüşe sahip oldukları görülmektedir. Ancak sivil toplum kuruluşları ve üniversiteler koruma, planlama ve miras yönetimi konularında katılımcı anlayışın benimsenmesine yönelik sempozyumlar, kongreler ve çalıştaylar düzenlemekte, kent atölyelerinde uzmanlar ve yöre halklarını buluşturmak konularında karar verici mekanizmalardan daha aktif çalışmalar yapmaktadırlar.

Üsküdar kıyı bandı yerli ve yabancılar için bir çekim noktası olup, kentin aktarım merkezi konumundadır. Çok yoğun göç almasının koruma çalışmalarını olumsuz etkilediği ve pek çok proje çalışmasının söz konusu olduğu paydaşlar tarafından belirtilmektedir. Balaban Tekkesi restorasyon projesi, MARMARAY Projesi, eski kaymakamlık binası restorasyon projesi, Selimiye Hamamı projesi bu projelerden bazılarıdır.

Kültürel mirasa ilişkin mevzuat incelendiğinde, İstanbul Sismik Riskin Azaltılması ve Acil Durum Hazırlık Kapasitesinin Arttırılması Projesi (İSMEP) [49]'te belirtildiği üzere; günümüzde Türkiye'de kültür ve tabiat varlıklarının her türlü araştırmasının, korunmasının ve yönetiminin kurallarını belirleyen düzenleme 1983 yılında kabul edilen 2863 sayılı Kültür ve Tabiat Varlıklarını Koruma Kanunu'dur.

Bu yasada 2004 yılında, 5226 sayılı yeni kanun ile kültürel miras yönetimi ve finansmanı konularında dünyadaki yeni açılımları yansıtan değişikler yapılmıştır. Yasanın üçüncü maddesi "kültür varlıkları", "tabiat varlıkları", "sit”, "ören yeri” kavramlarını tanımlamaktadır. Türkiye, birçok Avrupa Konseyi ve UNESCO (United Nations Educational, Scientific and Cultural Organization) kararını onaylamış; Venedik Tüzüğ̈̈ (1964), Dünya Kültürel ve Doğal Mirası Koruma Sözleşmesi (1972), Avrupa Mimari Mirası Koruma Sözleşmesi (1985), Avrupa Arkeoloji Mirasının Korunması Sözleşmesi’ni (1992) taraf olarak iç hukuk belgesi haline getirmiş̧ir.

\section{IV.SONUCLAR VE ÖNERILER}

Kültürel odaklı peyzaj biyografisinin oluşturulması kapsamında İstanbul ili Üsküdar İlçesi, Üsküdar Meydanı ve Selimiye Kışlası kıyı hattı ve yaklaşık 1 km kıyı gerisinde kalan bölgeyi içeren çalışmada Yapılan analizler, anket çalışması, paydaş görüşleri, uzman değerlendirme formları sonucunda aşağıda yer alan sonuç ve önerilere ulaşılmıştır:

> Çalışma alanı içerisinde uzman gözlem formları kapsamında İsmail Ağa Çeşmesi, Şifa Hamamı, Ayşe Sultan çeşmesi, Salacak Fatih Çeşmesi, Salacak Fatih Camii, Daye Kadın Çeşmesi ve Başkadın Çeşmesi okunabilirlik, tasvir edilebilirlik, doğallık, sahip çıkma ve görsel ölçek kavramları açısından yetersiz bulunmuşlardır. Bu kültürel miras elemanları çoğunlukla tarihi çeşmeler olup, Üsküdar'ın eski, dar ve eğimli sokakları, yapısal yoğunluk arasında algilanamamaktadırlar.

> Camiler, külliyeler, Selimiye kışlası ve kentsel açık ve yeşil alanlar nispeten daha algılanabilir, daha iyi korunmuş, kent halkının farkında olduğu, günümüzde de geçmiş amacına uygun olarak kullanılan alanlardır. 
Çalışma alanı peyzaj biyografisi ortaya konulduğunda, alanda yer alan kültürel miras alanlarının Bizans dönemi ve Osmanlı dönemi eserleri olduğu, 1750 yılında yaşanan Üsküdar yangınında sokakların dar olması, yapıların ahşap olması nedeni ile 100 evin yandığı, kuruluşundan beri İstanbul'un 550'den fazla depremle sarsılmış en önemlisinin 10 Eylül 1509 yılında yaşandığı ve büyük yıkıma sebep olduğu görülmektedir. İstanbul'da tarihte yaşanan don olayları ile Boğaziçi ve Haliç'in donduğu halkın Üsküdar'dan Galata'ya yürüyerek geçtiğine dair belgeler bulunmaktadır. Don olaylarının tarihte sik sik tekrarlandığı sonuncusunun 1954 yılında yaşandığı belirtilmektedir. 1. Dünya Savaşı ve sonrasında İstanbul'a havadan yapılan saldırılarda tahribata uğratıldığı belirlenmiştir.

$>$ Çalışma alanına ilişkin peyzaj biyografisi irdelendiğinde pek çok yapının kuruluşundan günümüze değişimler geçirdiği, değişimin özellikle 21. yy'ın ikinci yarısından sonra çok hızlandığı, 10'ar yıllık periyotlarda dahi değişimin olumsuz yönde hızlandığ saptanmıştır.

$>$ Alanda yer alan kültürel miras elemanlarına ilişkin restorasyon çalışmaları dış cephe uygulamaları ve sağlamlaştırma çalışmaları ile sınırlı kalmakta, yapıların çevreleri ve İstanbul kimliği ile uyumu, sokak yapısı ve algılanabilirliği, çevredeki açık alanların ve yapıların yoğunluğu arasındaki ilişki çoğunlukla göz ardı edilmektedir.

$>$ Alanda yaşayan halk, kültürel miras elemanlarının önemin farkında olmasına rağmen, koruma ve algılanabilirliklerinin arttırılması, koruma-dengesi olup olmadığı, kentleşme çalışmalarının kültürel dokuya zarar verip vermediği konusunda kararsız olduklarını belirtmektedirler. Kentsel kültürel mirasın yönetimi konusunda paydaşlardan karar vericiler daha baskın paydaşlar olup, vatandaşlar fikir belirtmek konusunda çekimser ve pasif kalmaktadırlar. Katılımcı yönetim planlarına ulaşabilmek ve sorunları çözümleyebilmek için katılım kültürünün öneminin anlaşılması gerekmektedir.

Çalışma alanında yer alan kültürel miras alanlarının algılabilirliklerini arttırmaya ve gelecek kuşaklara aktarırken niteliğini yitirmeden devamlılık sağlanmasına yönelik öneriler geliştirilmiştir. Buna göre;

Okunabilirlik açısından;

> Tarihi çevrelerde, kültürel mirasın bulunduğu mahallelerde yeni yapılan yapılar, bu değerleri gölgelemeyecek, okunabilirliğini ve algılanabilirliğini azaltmayacak şekilde konumlanmalı ve tasarlanmalıdır.

Kültürel miras alanlarının yakın çevrelerinde araç trafiği iyi bir şekilde planlanmalıdır

Tutarlılık ve mekan duygusu açısından;

$>$ Kültürel miras alanların çevresinde yapılacak olan yapısal ve bitkisel tasarımlarda bütünsellik ve uyum, mekânın algılanabilirliği ön planda olmalıdır.

> Tarihi doku alanlarının çevresinde kullanılacak olan her türlü sert zemin döşeme ve yapısal malzeme özenle seçilmeli, dokuyu değiştirmemeli veya uyumsuzluk yaratmamalıdır.

$>$ Tarihi çevrelerde yürütülecek kentsel peyzaj planlama çalışmalarında, çevrenin doğal ve kültürel yapı bütünlüğünün korunması dikkate alınmalıdır.

Kültür turizminin canlanması sağlanmalıdır.

Tarihsellik ve sahip çıkma açısından;

Yapılan restorasyon çalışmalarında yapının aslına sadık kalınmalı, yapının tarihi silueti korunmalıdır. İşlevsiz, atıl yapılar değerlendirilip yeniden işlevlendirilmelidir. 
> Tarihi yapıların korunmasında hem çevre ile hem de yapının yapıldığı dönemin sosyal-kültürel özellikleri dikkate alınarak koruma-kullanma sağlanmalıdır.

> Geçmişle gelecek arasında bir köprü kuran bu miras alanlarının korunmasında halkın bilgilendirilmesi sağlanmalı, bu değerlerin insanlığın ortak mirası olduğu bilgisi halka aşılanmalı, farkındalık oluşturulmalı ve özellikle gelecek neslin bilinçli ve korumacı bir yaklaşım benimsemeleri sağlanmalıdır.

> Çalışma alanı gibi tarihi tüm kentlerde geleneksel çarşılar yeniden aktif hale dönüştürülmeli, kent meydanları yeniden düzenlenmeli, Konaklar ve yalılar bahçe alanları ile restore edilerek yeniden işlevlendirilmelidir.

Görsel ölçek ve mekan duygusu açısından;

Tarihi çevrede dokuyla uyumlu, görüntü kirliliği yaratmayacak reklam panoları, tabelalar, aydınlatma ve elektrik direkleri vb. elemanların seçim ve kullanımına özen gösterilmelidir. Bina cepheleri tarihi doku ile uyumlu olmalıdır.

Doğallık ve geçicilik açısından,

Kültürel miras alanlarında bulunan mevcut anıt ağaçlar ve yeşil doku korunmalı, tahrip olan ağaçların bakımı yapılıp alana tekrar kazandırılmalıdır

Sonuç olarak çalışma alanı için kentsel kültürel miras envanteri oluşturulmuş, peyzaj biyografileri ortaya konulmuştur. Peyzaj biyografileri, kültürel mirasa yönelik tehditlerin algılanmasını, geçmiş süreçlerden, yıkımlardan ve yapımlardan çıkarımlarda bulunmayı, kentsel kültürel miras elemanlarının çevreleri ile okunabilirliğini kolaylaştırmaktadır. Plancılara, tasarımcılara, karar vericilere ve kentlilere geçmiş hataları tekrarlamadan, mekânı tanıma, koruma ve/veya yeniden işlevlendirme olanağı sunmaktadır. Çalışma alanı İstanbul 6 numaralı Kültür Varlıklarını Koruma Bölge Kurulu Müdürlüğü sorumluluğunda olup, sadece bu alan için değil, Yazgan ve Çelik (2007) tarafından da vurgulandığ üzere Türkiye'de koruma bölge kurullarının oluşumunda belirtilen Arkeoloji, Sanat Tarihî, Hukuk, Mimari, Şehir ve Bölge Planlama bilim dallarına ek olarak Peyzaj Mimarlığı bilim dalının da yer alması gerekmektedir.

\section{KAYNAKLAR}

[1] F. P. Arabacıoğlu, "Sur-Kent İlişkisinin Çevre Düzenleme Kriterleri Açısından Değerlendirilmesi”, Doktora Tezi , Fen Bilimleri Enstitüsü ,Yıldız Teknik Üniversitesi, İstanbul, Türkiye, 2007.

[2] C. Kurtar, M. Somuncu, "Kentsel Kültürel Mirasın Korunması ve Sürdürülebilirliği: Ankara Hamamönü Örneği," Yüksek Lisans Tezi, Sosyal Bilimler Enstitüsü, Ankara Üniversitesi, Ankara, Türkiye, 2012.

[3] F.P. Arabacioğlu, I. Aydemir, "Tarihi Çevrelerde Yeniden Değerlendirme Kavramı," YTÜ Mimarlı. Fakültesi E-Dergisi, c. 2, s. 4, ss. 204-212, 2007.

[4] Y. Tosun, "Kültürel Mirasın Korunmasında Üst Ölçekli Projelerin Rolü 2010 Avrupa Kültür Başkenti İstanbul ve Fatih Suriçi’ne Etkileri", Yüksek Lisans Tezi, Fen Bilimleri Enstitüsü ,Mimar Sinan Güzel Sanatlar Üniversitesi, İstanbul, Türkiye, 2008. 
[5] D. Çelik ve M. Yazgan, "Kentsel Peyzaj Tasarımı Kapsamında Tarihi Çevre Korumaya Yönelik Yasa ve Yönetmeliklerin İrdelenmesi," Bartın Orman Fakültesi Dergisi, c. 9, s. 11, ss. 1-10, 2007.

[6] H., Erkal, "Unesco Yaşayan İnsan Hazineleri Ulusal Sistemleri’nin, Somut Olmayan Kültürel Mirasın Yaşatılmasına ve Gelecek Kuşaklara Aktarılmasına Etkisi Üzerine Bir İnceleme", Yüksek Lisans Tezi , Sosyal Bilimler Enstitüsü Türk Halkbilimi Anabilim Dalı, Gazi Üniversitesi, Ankara, Türkiye, 2010

[7] D. Ceylan, A. Korkut ve T. Kiper, "Tarihi Çevre Yenileme Çalışmalarında Kentsel Peyzaj Planlama Anlayışı: Edirne Örneği," Yüksek Lisans Tezi, Güzel Sanatlar ve Tasarım Fakültesi Peyzaj Mimarlığı Bölümü, Namık Kemal Üniversitesi, Tekirdağ, Türkiye, 2014.

[8] Anonim, (12 Nisan 2018). [Online]. Erişim:http://www.avrupakonseyi.org.tr/tur/antlasma/

[9] E. Kaska, "Avrupa Peyzaj Sözleşmesi (Aps) ve Türkiye'deki Uygulamaların İrdelenmesi," Yüksek Lisans Tezi, Fen Bilimleri Enstitüsü, Ankara Üniversitesi, Ankara,Türkiye, 2012.

[10] Türk Dil Kurumu, (2019,5 Mart). Biyografi Kavram1, Türk Dil Kurumu Erişim: http://www.tdk.gov.tr/

[11] Kolen, J., "Landscape biographies: Geographical, historical and archaeological perspectives on the production and transmission of landscapes", Amsterdam University Press, 437, Amsterdam, 2015.

[12] N. R. Gerritsen, V.D. Heijden, K., Bosma, C. ve J. Kolen, "Landscape Biography as Research Strategy: The Case of the South Netherlands Project," Landscape Research, c. 34, s. 3, ss. 337-359, 2009.

[13] T. Lemaire, "Archaeology Between The Invention and Destruction of Landscape," Archaeological Dialogues, c. 4, s. 1, ss. 5-21, 1997.

[14] S. Sütunç, "Bir Sulak Alanı Biçimlendiren Çok Katmanlı Dinamiklerin Peyzaj Biyografisi Yaklaşımıyla Araştııılması: Bafa Gölü Örneği," Doktora Tezi, Fen Bilimleri Enstitüsü, Peyzaj Mimarlığı Anabilim Dalı, Ankara Üniversitesi , 2018.

[15] Anonim, (5 Aralık 2018). [Online]. Erişim: http://www.kmkm.org.tr/tr-tr/kulturel-mirasi-korumadernegi

[16] Anonim,(24 Mart 2019). [Online]. Erişim: https://earth.google.com/

[17] H. Tüfekçioğlu Kuğu, "Tarihsel Çevrede Görsel Peyzaj Kalite Değerlendirmesi İstanbul Yedikule Örneği," Yüksek Lisans Tezi, Fen Bilimleri Enstitüsü Peyzaj Mimarlığı Anabilim Dalı ,̇́stanbul Teknik Üniversitesi, İstanbul, Türkiye,2008.

[18] Altunışık, R., Coşkun, R., Bayraktaroğlu, S., Yıldırım, E., Sosyal Bilimlere Araştırma Yöntemleri: SPSS Uygulamal1, 9.Baskı,Sakarya,Türkiye: Sakarya Kitapevi, 2017. 
[19] O. Uzun, P. Gültekin, Y.S. Gültekin, “Assessment of Participatory Ecotourism Planning and Management Using by Different Stages of Basin Scale", 1st International Conference, on Sea and Coastal Development in The Frame of Sustainability, 182-192, 2015.

[20] P. Gültekin, Y.S. Gültekin, O. Uzun, “Türkiye için Katılımcı Ekoturizm Planlamasında Paydaş Analizi ve Paydaş Yönetişimi”. 2. Uluslararası Osmaneli Sosyal Bilimler Kongresi, 1464-1472, 2016.

[21] P. Gültekin, Y.S. Gültekin, O. Uzun, "Katılımcı Planlamada Yerel Halk Ekoturizm İlişkisi Düzce Aydınpınar Köyü Örneği”. III. Uluslararası Odun Dışı Orman Ürünleri Sempozyumu, 2014.

[22] P. Gültekin, O. Uzun, Y.S. Gültekin, "Ecotourism Governance in Basin Scale: An Example of Western Blacksea Basin", Current Trends in Science and Landscape Management, ST. Kliment Ohridski University Press, Bilyana, Basım sayısı:1, Sayfa Sayı1 725, ISBN:978?954?07?4338?7, 2017.

[23] P. Gültekin, Y.S. Gültekin, O. Uzun, "Ekoturizmde Çatışma Yönetiminin Düzce Uğursuyu ve Aksu Havzaları Örneğinde İrdelenmesi”, IV. Ormanc1lıkta Sosyo-ekonomik Sorunlar Kongresi, 1(1), 29-43,2015.

[24] İ. Orman, "Mihrimah Sultan Külliyesi," Test Yayını, İstanbul, Türkiye Türkiye Diayent Vakfı İslam Ansiklopedisi c. 30, s. 42, 2016.

[25] S. Dağtaş, "Üsküdar Meydanı'nın Ve Bu Meydanı Tanımlayan Anıtsal Yapıların Tarihsel Süreçteki Değişimi," Yüksek Lisans Tezi, Fen Bilimleri Enstitüsü, Restorasyon Anabilim Dalı, Koruma Yenileme Programı Mimar Sinan Güzel Sanatlar Üniversitesi, İstanbul, Türkiye, 2010.

[26] Kılıç, A., "Tarihi Eserleri ile Üsküdar," İstanbul,Türkiye:Üsküdar Belediyesi Yayınları, 2017.

[27] A., Ertuğrul, "XIX. Yüzy1l İstanbul Kentsel Dönüşümü’nde Üsküdar ve Koruma Sorunlar1," Doktora Tezi, Fen Bilimleri Enstitüsü, Mimarlık Anabilim Dalı, Restorasyon Programı, İstanbul Teknik Üniversitesi, İstanbul,Türkiye, 2011.

[28] Anonim, (14 Ocak 2019). [Online]. Erişim:http://www.tas-istanbul.com/portfolioview/uskudar-carsi-selman-aga-camii/

[29] Haskan M.N., "Yüzyıllar Boyunca Üsküdar (Cilt 3),"3.Bask1,İstanbul,Türkiye: Marmara Reklam ve Pazarlama Ltd. Şti,2011.

[30] G.E., Canca, "Gülnuş Emetullah Valide Sultan/Yeni Valide Külliyesinin Lale Devri Mimarisi İçindeki Yeri," Üsküdar Sempozyumu I’ de sunuldu, Üsküdar, 2004.

[31] Mermutlu B. ve B., Bolu, "Üsküdar Balaban Tekkesi," 25.Bask1, İstanbul,Türkiye: Ege Reklam Basım Sanatları, 2014.

[32] C., Baştemur, "Mimar Sinan Rotasının Doğal ve Kültürel Peyzaj İzleri," Doktora Tezi, Fen Bilimleri Enstitüsü, Peyzaj Mimarlığı Anabilim Dalı, Ankara Üniversitesi, Ankara, Türkiye, 2013.

[33] S., Derin, "Üsküdar Rum Mehmet Paşa Camii’nde Onarımlar," Uluslararası Üsküdar Sempozyumunda sunuldu, Manisa, 2014. 
[34] İ., Özgül, "Üsküdar'ın Kentsel-Mekânsal Dönüşümü Bağlamında Rum Mehmed Paşa Camisi’nin Koruma Sorunları," Yüksek Lisans Tezi, Fen Bilimleri Enstitüsü, Kültür Varlıklarını Koruma Yüksek Lisans Programı, Kadir Has Üniversitesi, İstanbul, Türkiye, 2015.

[35] S., Şahin, "Üsküdar'da III. Ahmet Dönemine Ait Dört Çeşme ve Osmanlı Mimarisinde Nadir Görülen Bir Kemer Tipi Üzerine," Uluslararası Üsküdar Sempozyumu Vll de sunuldu, Üsküdar, 2014.

[36] Anonim, (30 Ocak 2019). [Online]. Erişim:https:// www.uskudar.bel.tr/ tr/main/ erehber/hamamlar/41/eski-hamam-rum-mehmet-pasa-hamami/384

[37] Çeçener B., Üsküdar Merkez Mahalleleri Osmanlı Dönemi Su Uygarlığı,1.Bask1, İstanbul,Türkiye:EP İletişim, 2007.

[38] S., Karaosman ve İ.Ö., Eren, "Üsküdar'da Çevre Verilerinin Osmanlı Donemi Camilerinin Yerleşimine Etkisi," Üsküdar Sempozyumu I Mayıs Bildirilerinde sunuldu, Üsküdar, 2003.

[39] İ. Yıldırım ve N.K., Yıldırım, "Dünden Bugüne Doğancılar Caddesi," Uluslararası Üsküdar Sempozyumu VII de sunuldu, Üsküdar, 2012.

[40] S., Kararmaz, "Bir Semt Momografisi:Salacak," Final Ödevi, İstanbul, 2017.

[41] Güleryüz, H.S., "Âbideler Şehri İstanbul," Osmanlı Devri Eserleri,İ́stanbul,Türkiye, 2016.

[42] S.,Yariş, "Üsküdar'da Yer Alan Bir Grup Cami Haziresindeki Mezar Taşları," Doktora Tezi, Sosyal Bilimler Enstitüsü Sanat Tarihi Ana Bilim Dalı, Atatürk Üniversitesi, Erzurum,Türkiye, 2015.

[43] O., Sezer, "Üsküdar Sinan Paşa ve Solak Sinan Camiileri (Müştemilatlarıyla Birlikte)," Bitirme Tezi , Fen Edebiyat Fakültesi, Sanat Tarihi Bölümü, Sakarya Üniversitesi, Sakarya,Türkiye, 2016.

[44] K., Öztürk, "Üsküdar Harem Semtinin Tarihi Gelişimi," Yüksek Lisans Tezi, Türkiyat Araştırmaları Enstitüsü Türk Sanatı Anabilim Dalı, Marmara Üniversitesi,İstanbul, Türkiye, 2008.

[45] Üsküdar Belediyesi, Üsküdar Belediyesi 2015-2019 yılı Stratejik Planı.

[46] M.G., Ramazanoğlu, "Osmanlı Yenileşme Hareketleri İçerisinde Selimiye Kışlası ve Yerleşim Alanı, Doktora Tezi , Fen Blimleri Enstitüsü Mimarlık Anabilim Dalı, Yıldız Teknik Üniversitesi, İstanbul,Türkiye, 2003.

[47] Anonim, (22 Mart 2019). [Online]. Erişim: https:// www.academia.edu/ 23193829/ B\%C3\%BCy\%C3\%BCk_Selimiye_Camii

[48] Koca Y.N., Khrysopolis, Scutari, Eskidar, Usgüdâr: Tarihî Haritalarda Üsküdar, Uluslararas1 Üsküdar Sempozyumu VIII unda sunuldu, Kocaeli, 2014.

[49] Anonim, (12 Haziran.2019). [Online]. Erişim:http://www.guvenliyasam.org/wpcontent/uploads/2016/02/KULTUREL.pdf 